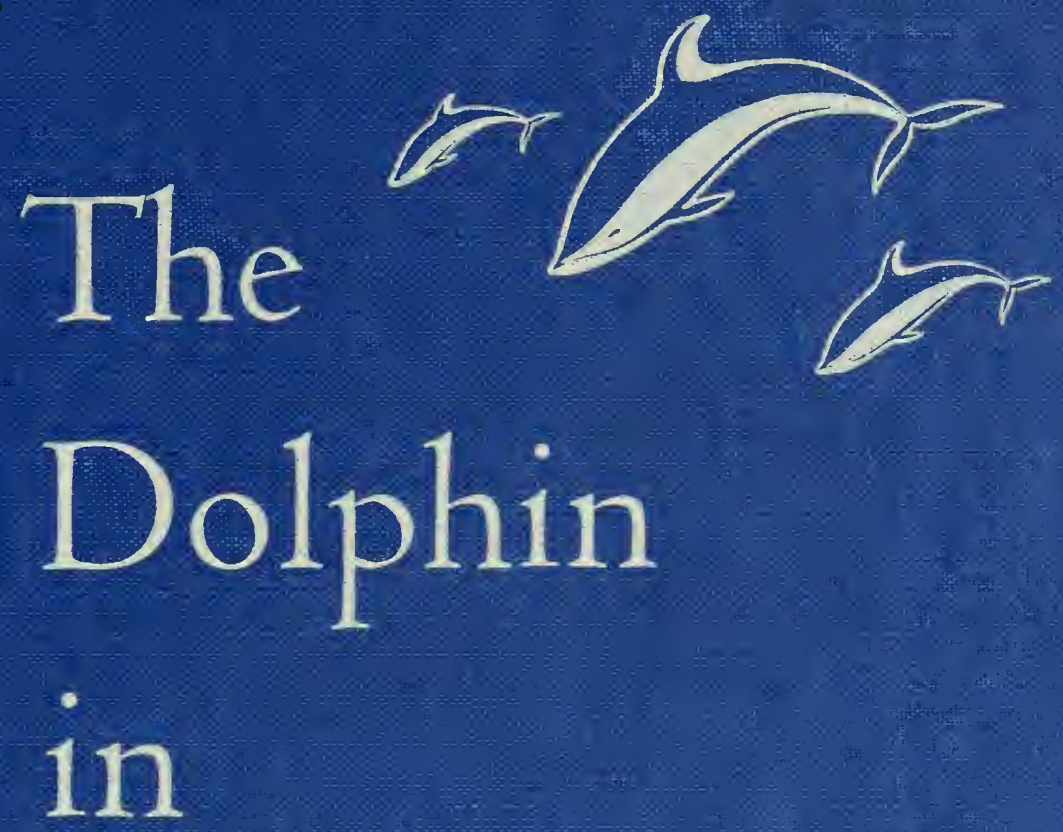

History 


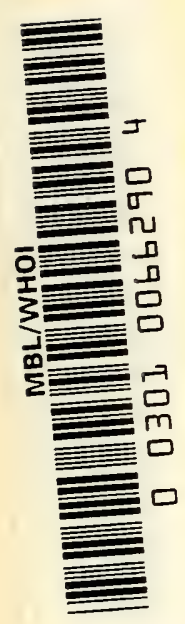






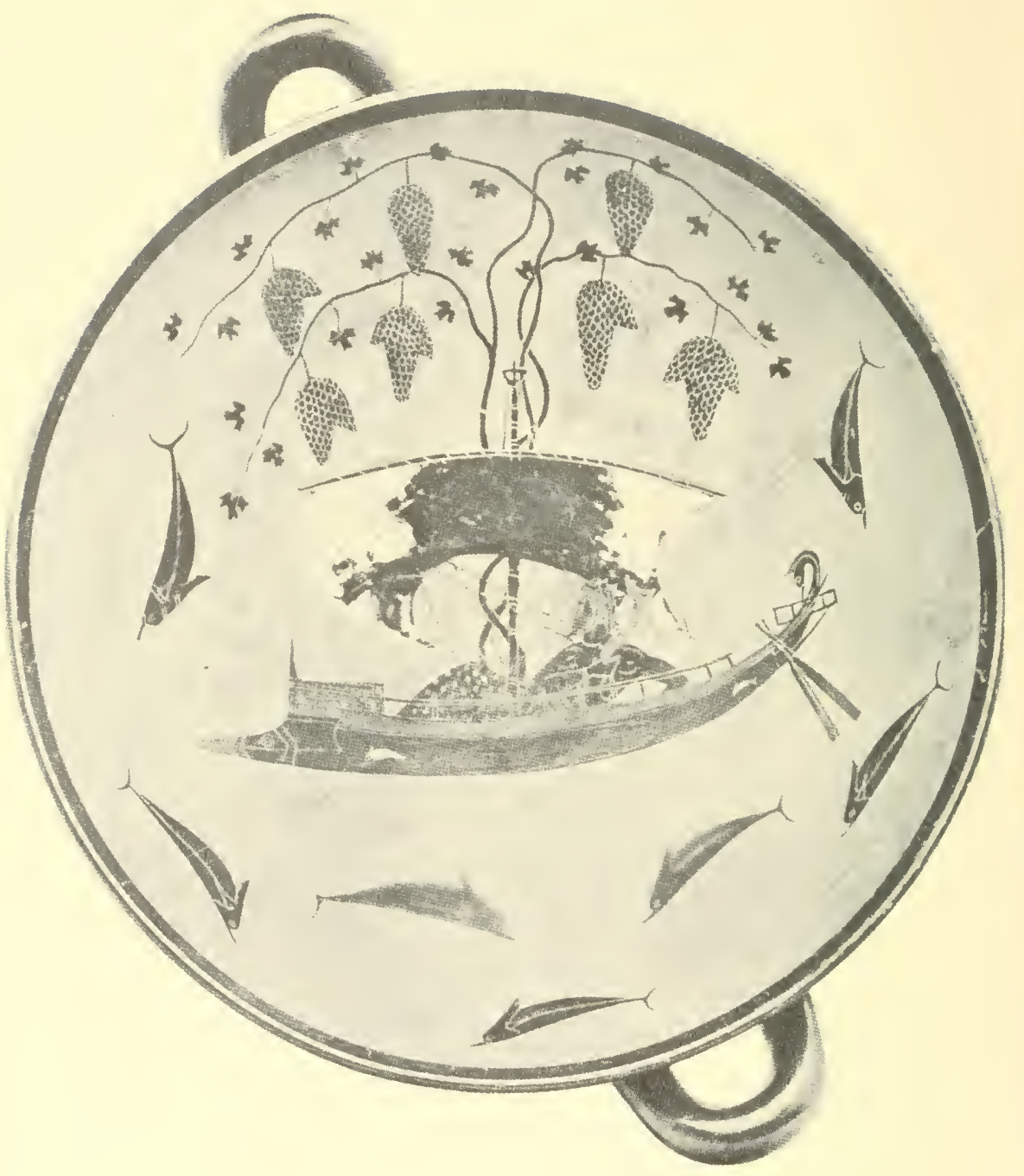

The Dionysos Cup by Exekias, c. $54^{\circ}$ B.C.

Staatliche Antikensanmlungen, Munich. Photograph by Dr. Max Hirmer. 


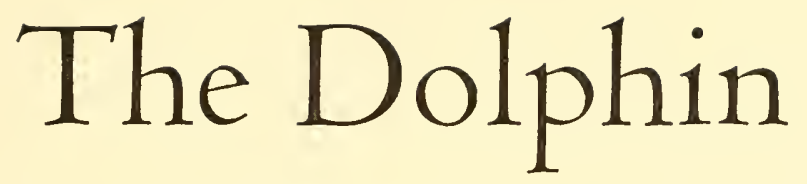

in History

Papers delivered by Asbley Montagu and Jobn C. Lilly at a symposium at the Clark Library, 13 October 1962

WILLIAM ANDREWS CLARK MEMORIAL LIBRARY University of California, Los Angeles 1963 



\section{Foreword}

$\mathrm{R}_{\text {Ecently the dolphin has become the focus of }}$ much scientific interest and investigation which have led to flattering pronouncements about its remarkable intelligence, amiability, and astonishing friendliness towards man. It was in consequence of such activities that a symposium was held at the William Andrews Clark Memorial Library to consider the background to contemporary studies of the dolphin. The presentations of Dr. Ashley Montagu and Dr. John C. Lilly were received so favorably that it was decided to make them more widely available in the present form.

As will be readily apparent to any reader, Dr. Montagu has demonstrated conclusively that had the writings of the ancients been heeded we should long since have paid proper respect to this intelligent mammal, and Dr. Lilly has reinforced such classical appreciation by an account of his own astonishing observations of dolphin behavior. It is to be hoped that these two accounts will contribute to a lasting appreciation of our remarkable aquatic friend.

\section{D. O'Malley}

DIVISION OF MEDICAL HISTORY

UNIVERSITY OF CALIFORNIA, LOS ANGELES 



\title{
THE HISTORY OF THE DOLPHIN
}

\author{
by Ashley Montagu
}

The friendly Dolphin, while within the maine,

At libertie delightes, to sport and play,

Himselfe is fresh, and doth no whit retaine

The brinish saltnes of the boundless Sea

Wherein he lives. Such is the secret skill

Of Nature working, all thinges at her will.

Henry Peacham, Minerva Britanna, I612 



\section{The History of the Dolphin}

\section{By ASHLEY MONTAGU}

I have met with a story, which, although authenticated by undoubted evidence, looks very like a fable. Pliny the Younger

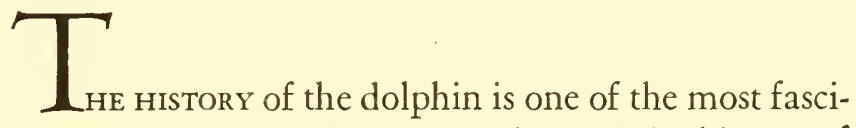
nating and instructive in the historiography and the history of ideas in the western world. Indeed, it provides one of the most illuminating examples of what has probably occurred many times in human culture-a virtually complete loss of knowledge, at least in most segments of the culture, of what was formerly well understood by generations of men. "Not in entire forgetfulness" in some regions of the world, but certainly in "a sleep and a forgetting" in the most sophisticated centers of the western world.

Dolphins are mammals. They belong in the order Cetacea, suborder Odontoceti, family Delphinidae. Within the Delphinidae there are some twenty-two genera and about fifty-five species. The count includes the Killer Whale, the False Killer Whale, the White Whale, and the Pilot Whale, all of which are true dolphins. There are two subfamilies, the Delphinapterinae, consisting of the two genera Monodon monocerus, the Narwhal, and Delphinapterus leucas, the White Whale or Beluga. These two genera are distinguished by the fact that none of the neck vertebrae are fused, whereas in all remaining genera, embraced in the subfamily Delphininae, at least the first and second neck vertebrae are fused. 
It was Aristotle in his History of Animals (52Ib) who first classified whales, porpoises, and dolphins as Cetacea, $\tau \dot{a} \kappa \eta \dot{\tau} \tau \eta$

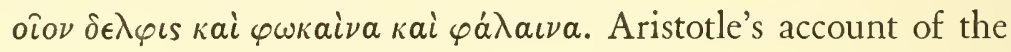
Cetacea was astonishingly accurately written, and quite evidently from firsthand knowledge of these animals.

While most dolphins are inhabitants of the seas, there are some that live in rivers, and quite a few that are denizens of fresh-water rivers removed many miles from the sea. With one exception the diet of dolphins is principally fish. The one exception is Sotalia teuszii, which lives in the Kamerun River, and is believed to feed exclusively on vegetable matter. The Ting Ling dolphin (Lipotes vexillifer) lives in Ting Ling Lake, six hundred miles up the Yang-tse-Kiang. Another dolphin, the Susu or Ganges dolphin (Platanista gangetica) of Brahmapootra, the Ganges, and the Indus, has lenseless eyes and is almost blind. The fresh-water dolphins belong in the family Platanistidae.

It is of interest to note that, in connection with the vegetable feeding habits of the Kamerun dolphin, Lycophron, in his Alexandra, makes his dolphins feed on trees, and Ovid, in the Metamorphoses (III, I, 202), describes a flood in which the dolphins take possession of the woods. Nonnus Panopolitanus, in the Dionysiaca (VI, 265-266), also describes dolphins as feeding on trees.

The normal range of length of dolphins is from 5 to i 4 feet; the larger species, the whales, are considerably longer. Brain weight is between 1600 and 1700 grams in the familiar dolphins, and reaches 9200 grams and more in the whales. The large brain is associated with what, all observers familiar with these animals agree, is a quite considerable intelligence.

Here we must pause to make a plea for the proper usage of common names. The term "porpoise" refers to the small, beakless Delphinidae, which have a triangular dorsal fin and spadeshaped teeth. The name "dolphin" embraces all other members of the family, except the larger forms, which are called whales. 
The porpoises mostly belong in the genus Phocaena, the best known species of which, the Common Porpoise (Phocaena phocaena), never reaches a length exceeding 6 feet and weighs roo to r2o pounds. There are some six species. The finless black porpoise constitutes the only other genus with a single species Neomeris phocaenoides.

All porpoises are dolphins. The Bottle-Nosed Dolphin, Tursiops truncatus, is sometimes called a porpoise. This is incorrect. Tursiops is a true dolphin, and should not be called what it is not.

Here we shall be principally concerned with the Bottle-Nosed Dolphin and with the Common Dolphin. The Bottle-Nosed Dolphin has a short, well-defined snout two or three inches long, and is characterized by a prominent fin in the middle of the back. Coloration is dark above and light below. Gestation lasts some ten months, birth is monotocous, and the young are suckled for about 18 months. The tail is delivered first, and the infant, about three feet long and weighing about twenty-five pounds, is immediately quite active, though much in need of the care of its devoted mother. The infant will eventually grow to be between II and I2 feet in length, and weigh about 300 kilograms. Tursiops has an enormously wide range, being commonest along the Atlantic coast of America, from Maine to Florida, and occurs in the Bay of Biscay in the Mediterranean Sea, and as far south as New Zealand.

The Common Dolphin, Delphinus delphis, is readily recognized by its well-defined narrow beak and distinctive coloration. The beak is some 5 to 6 inches narrower and finer than in the Bottle-Nosed Dolphin, and is sharply marked off by a deep Vshaped groove from the low reclining forehead. The Common Dolphin reaches a length up to $81 / 2$ feet. Its range of distribution is very wide, for it may be met in any temperate or warm sea throughout the world, and occurs at times in vast schools.

Whether the dolphin of classical antiquity is Delphinus or Tursiops is not usually determinable, although each undoubt- 
edly played its independent role in the stories told of dolphins. From the recorded evidence available to us it is clear that, except for the larger species, the whales, all dolphins appear to be characterized by playfulness and friendliness toward man. There are, however, differences which appear to express themselves mostly in captivity. At least, Tursiops adjusts much better to captivity than does Delphinus. At marine studios Tursiops has established itself as a highly intelligent, playful, and friendly performer. Delphinus, on the other hand, while naturally all these things, in captivity tends to be timid and not very playful.

The Common and Bottle-Nosed Dolphins are those best known to the western world, but many of the traits which have recently been rediscovered concerning these creatures have been well known to other peoples for millennia. It is only a certain segment of the western world, its more sophisticated representation, and particularly the learned world, which dismissed as myths the tales told about dolphins in classical antiquity. And this is the real burden of the story I have to tell you. Some of these antique tales may have been myths, but as we shall see, many of them were not, and undoubtedly a number of the myths were based on real events partially embroidered by the imagination and improved, like good wine, by time. But good wine needs no bush, and I shall sample this wine as palatably as I find it.

The earliest representation of a dolphin I have been able to find is from a pictographic seal from Crete, estimated to date from 3500 to 2200 B.C. The earliest painting of a dolphin thus far recovered is from the ancient Peloponnesian city of Tiryns. The date is about 1600 B.C. In that city it is also represented in stucco floors. Several good examples of dolphins are furnished by seventh century Corinthian art. The dolphin is also well represented in Minoan art. In Cyprus it is frequently represented in Late Helladic vases, shards, amphorae, in metalwork, en- 
gravings, and in stucco floors as at Tiryns. Among the importations from Crete into Helladic art appear to have been certain stylized forms of the dolphin.

An early literary reference to the dolphin occurs in Aesop's fable, "The Monkey and the Dolphin." During a violent storm a ship was capsized, and among those thrown into the water was a monkey. Observing its distress a dolphin came to its rescue, and taking the monkey upon its back the dolphin headed for shore. Opposite Piraeus, the harbor of Athens, the dolphin inquired of the monkey whether he was an Athenian. "Oh, yes," replied the monkey, "and from one of the best families." "Then you know Piraeus," said the dolphin. "Very well, indeed," said the monkey, "he is one of my most intimate friends." Whereupon, outraged by so gross a deceit, the dolphin took a deep dive and left the monkey to its fate.

I take it that ever since that day monkeys have very sensibly refrained from speech. It is far better to remain silent even at the risk of being taken for a fool or a rogue, than to open one's mouth and remove all doubt.

Aesop flourished about 600 B.C. His story suggests a considerable knowledge of the ways of dolphins, and this indicates that knowledge of the dolphin was already old in his time.

There are several variant Greek myths on the origin of the dolphin. All of them relate to Dionysos. In one version Dionysos is an adult, in another he is a child. The first group of legends represent the epiphany of Dionysos, symbolizing the battle between winter and summer. Winter is represented by the death of Dionysos who disappears into the water, from which he is brought back on the top of a dolphin as the returning springtime (Apollodorus, III, 5, 3). Another version has Dionysos, whether as child or adult varies, being conveyed by ship to Naxos by Tyrrhenian mariners. The latter conceive the idea of kidnaping him. Dionysos senses their treachery, and bidding his companions strike up on their musical instruments, he produces a 
Bacchic wild dance in the mariners who throw themselves overboard and are changed into dolphins.

The popular belief in antiquity in the human intelligence of dolphins and their kindly feeling toward man was explained by the ancient writers in the light of the transformation of the Tyrrhenian pirates into dolphins. (See Lucian, Marine Dialogues, 8; Oppian, Halientica, I, 649-654, I098, V, 422, 519f; Porphyry, De Abstinentia, III, I6.) As Oppian (I, 1089) in his Halieutica has it, in William Diaper's charming translation:

So Dolphins teem, whom subject Fish revere, And show the smiling Seas their Infant-Heir.

All other Kinds, whom Parent-Seas confine,

Dolphins excell; that Race is all divine.

Dolphins were Men (Tradition hands the Tale)

Laborious Swains bred on the Tuscan Vale:

Transform'd by Bacchus, and by Neptune lov'd,

They all the Pleasures of the Deep improv'd.

When new-made Fish the God's Command obey'd,

Plung'd in the Waves, and untry'd Fins displayed,

No further Change relenting Bacchus wrought,

Nor have the Dolphins all the Man forgot;

The conscious Soul retains her former Thought.

The god of the golden trident who rules over the seas, Poseidon, would not have prospered in his wooing of Amphitrite if it had not been for the assistance of a dolphin, who apprized Poseidon of her hiding-place. For this service, as is well-known, Poseidon set the dolphin among the stars in the constellation which bears its name to this day.

It is interesting in this connection that in a modern Greek folktale from Zacynthos, Poseidon changes a hero who has fallen into the sea into a dolphin until such time as he should find a maiden ready to be his wife. After some time the dolphin rescues a shipwrecked king and his daughter, the princess by way of reward takes him for her husband, and the spell is broken (Bernhard Schmidt, Das Volksleben der Neugriechen, p. 135). 
The cult of Apollo Delphinus was initiated, so legend has it, by Icadius who, leaving his native land of Lycia, which he had named for his mother, set out for Italy. Shipwrecked on the way, he was taken on the back of a dolphin, which set him down near Mount Parnassus, where he founded a temple to his father Apollo, and called the place Delphi after the dolphin. For this reason the dolphin became among the things most sacred to Apollo (Servius, Commentarii in Vergilii Aeneidos, III, 332; also Cornificius Longus, De Etymis Deorum).

Herodotos, writing of Periander (f. 600 B.C.) tyrant of Corinth, tells one of the most famous of all stories of the dolphin (it is mentioned by Shakespeare in the first act of Twelfth Night). "In his time," writes Herodotos (b. 484 B.C.), "a very wonderful thing is said to have happened. The Corinthians and the Lesbians agree in their account of the matter. They relate that Arion of Methymna, who, as a player on the lyre, was second to no man living at that time, and who was, so far as we know, the first to invent the dithyrambic measure, to give it its name, and to conduct in it at Corinth, was carried to Taenarum on the back of a dolphin.

"He had lived, it is said, at the court of Periander, when a longing came upon him to sail across to Italy and Sicily. Having made rich profits in those parts, he wanted to recross the seas to Corinth. He therefore hired a vessel, the crew of which were Corinthians, thinking that there was no people in whom he could more safely confide; and, going on board, he set sail from Tarentum. The sailors, however, when they reached the open sea, formed a plot to throw him overboard and seize upon his riches. Discovering their design, he fell on his knees, beseeching them to spare his life, and making them welcome to his money. But they refused; and required him either to kill himself outright, if he wished for a grave on the dry land, or without loss of time to leap overboard into the sea. In this strait Arion begged them, since such was their pleasure, to allow him to mount upon 
the quarter-deck, dressed in his full costume, and there to play and sing, and promising that, as soon as his song was ended, he would destroy himself. Delighted at the prospect of hearing the very best singer in the world, they consented, and withdrew from the stern to the middle of the vessel: while Arion dressed himself in the full costume of his calling, took his lyre, and standing on the quarter-deck, chanted the Orthian [a very high pitched lively and spirited song]. His strain ended, he flung himself, fully attired as he was, headlong into the sea. The Corinthians then sailed on to Corinth. As for Arion, a dolphin, they say, took him upon his back and carried him to Taenarum, where he went ashore, and thence proceeded to Corinth in his musician's dress, and told all that had happened to him. Periander, however, disbelieved the story, and put Arion in ward, to prevent his leaving Corinth, while he watched anxiously for the return of the mariners. On their arrival he summoned them before him and asked them if they could give him any tidings of Arion. They returned for answer that he was alive and in good health in Italy, and that they had left him at Tarentum, where he was doing well. Thereupon Arion appeared before them, just as he was when he jumped from the vessel: the men, astonished and detected in falsehood, could no longer deny their guilt. Such is the account which the Corinthians and Lesbians give; and there is to this day at Taenarum an offering of Arion's at the shrine, which is a small figure in bronze, representing a man seated upon a dolphin." (The History of Herodotus, Clio, I, 23-24.)

Commenting on this tale the poet Bianor, in The Greek Anthology (Declamatory Epigrams, 308), remarks, "So the sea presumably contains fish whose righteousness exceeds that of mankind."

Coins of Methymna, in Lesbos, Arion's birthplace, show him riding a dolphin. In one form or another the dolphin is repre- 
sented on the coins of some forty Greek cities, and doubtless most Greeks knew the reason why.

Pliny the Elder, in his Natural History (IX, 8, 24-28), writes as follows:

"The dolphin is an animal that is not only friendly to mankind but is also a lover of music, and it can be charmed by singing in harmony, but particularly by the sound of the waterorgan. It is not afraid of a human being as something strange to it, but comes to meet vessels at sea and sports and gambols round them, actually trying to race them and passing them even when under full sail. In the reign of the late lamented Augustus a dolphin that had been brought into the Lucrine Lake fell marvellously in love with a certain boy, a poor man's son, who used to go from the Baiae district to school at Pozzuoli, because fairly often the lad when loitering about the place at noon called him to him by the name of Snubnose and coaxed him with bits of the bread he had with him for the journey,-I should be ashamed to tell the story were it not that it has been written about by Maecenas and Fabianus and Flavius Alfius and many others,- and when the boy called to it at whatever time of day, although it was concealed in hiding, it used to fly to him out of the depth, eat out of his hand, and let him mount on its back, sheathing as it were the prickles of its fin, and used to carry him when mounted right across the bay to Pozzuoli to school, bringing him back in similar manner, for several years, until the boy died of disease, and then it used to keep coming sorrowfully and like a mourner to the customary place, and itself also expired, quite undoubtedly from longing. Another dolphin in recent years at Hippo Diarrhytus on the coast of Africa similarly used to feed out of people's hands and allow itself to be stroked, and play with swimmers and carry them on its back. The Governor of Africa, Flavianus, smeared it all over with perfume, and the novelty of the scent apparently put it to sleep: it floated lifelessly about, holding aloof from human intercourse for some 
months as if it had been driven away by insult; but afterwards it returned and was an object of wonder as before. The expense caused to their hosts by persons of official position who came to see it forced the people of Hippo to destroy it. Before these occurrences a similar story is told about a boy in the city of Iasus, with whom a dolphin was observed for a long time to be in love, and while eagerly following him to the shore when he was going away it grounded on the sand and expired; Alexander the Great made the boy head of the priesthood of Poseidon at Babylon, interpreting the dolphin's affection as a sign of the deity's favour. Hegesidemus writes that in the same city of Iasus another boy also, named Hermias, while riding across the sea in the same manner lost his life in the waves of a sudden storm, but was brought back to the shore, and the dolphin confessing itself the cause of his death did not return out to sea and expired on dry land. Theophrastus records that exactly the same thing occurred at Naupactos too. Indeed there are unlimited instances: the people of Amphilocus and Taranto tell the same stories about boys and dolphins; and these make it credible that also the skilled harper Arion, when at sea the sailors were getting ready to kill him with the intention of stealing the money he had made, succeeded in coaxing them to let him first play a turn on his harp, and the music attracted a school of dolphins, whereupon he dived into the sea and was taken up by one of them and carried ashore at Cape Matapan."

A very similar but apparently quite independent account of these stories is given by the younger Pliny, in his Letters (IX, 23).

The elder Pliny then goes on to tell of the manner in which dolphins assist fishermen, which corresponds closely with the accounts given by recent observers of this cooperative activity between fishermen and dolphins. (For accounts of these see Antony Alpers, Dolphins, 146 sq.)

There are numerous other stories similar to those given by the 
Plinys from classical antiquity, but it is quite impossible to recount them here. ${ }^{1}$ What they all have in common is the friendliness of the dolphin for human beings, their rescue of them when they were thrown into the sea, their playfulness, especially with children, and their interest in almost any sort of sound. All these traits came to be regarded as mythical by later and more sophisticated ages, and Usener (Die Sintfluthsagen) comments on the effect that the prevalence of these tales had even upon the scientific thought of antiquity, making it difficult for such thinkers as Aristotle to get away from the belief in the dolphin's ability to carry a rider, and in its capacity for human feeling (Aristotle, History of Animals, 63ra). But Aristotle was right and Herr Usener wrong. The delightful thing about most of these myths is that they all appear to be based on solid fact, and not on the fancies attributed to the original narrators. Another typical modern gloss by a highly sophisticated writer, biologically not unknowledgeable, Norman Douglas, is the following: Commenting on the delphic mythology, he writes, "From these and many other sources, we may gather that there was supposed to exist an obscure but powerful bond of affection between this animal and humanity, and that it was endowed with a certain kindheartedness and man-loving propensity. This is obviously not the case; the dolphin cares no more about us than cares the haddock. What is the origin of this belief? I conjecture that the beast was credited with these social sentiments out of what may be called poetic reciprocation. Mankind, loving the merry gambols and other endearing characteristics of the dolphin, which

\footnotetext{
${ }^{1}$ Among the many well-known figures of classical mythology said to have been saved by dolphins from the sea are Eikadios, Enalos, Koiranos, Phalanthos, Taras, etc. In many other cases the corpses were brought ashore by a dolphin, which then expired on reaching land (similarly, with minor variations, was this so with Palaimon or Melikertes, Dionysios and Hermias of Iasos, Hesiod, and the boys already referred to from Baiae and Naupaktos). Similar incidents reappear in the writings of the hagiographers. Saints Martinianos of Kaisareia, Kallistratos of Carthage, Basileios the younger of Constantinople, were each saved from a watery grave by a couple of dolphins. The corpse of Saint Loukianos of Antioch was brought ashore by a large dolphin, which then expired on the sand. See Klement, Arion, I-64, and Usener, Die Sintfluthsagen, $138-180$.
} 
has a playful trick of escorting vessels for its own amusement, whose presence signified fair weather, and whose parental attachment to its offspring won their esteem-quite apart from its fabled, perhaps real, love of music or at least of noisy soundswere pleased to invest it with feelings akin to their own. They were fond of the dolphin; what more natural and becoming than that the dolphin should be fond of them?" (Birds and Beasts of the Greek Anthology, p. 16r.)

But Douglas was undisillusionedly wrong, and the dolphins are right, and so is the "mankind" that believed in their friendliness. Though pleased to see the dolphins play, it is to be regretted that Douglas did not mind his compass and his way, for:

Had the curteous Dolphins heard

One note of his, they would have dar'd

To quit the waters, to enjoy

In banishment such melody.

$$
\text { John Hall, } 1646 .
$$

In order to avoid any imputation that I may be attempting to play Euhemerus ${ }^{2}$ to the dolphin's tale, the facts may be allowed to speak for themselves-always remembering that facts never speak for themselves, but are at the mercy of their interpreters. All, then, that I am concerned to show here, by citing the contemporary evidence, is that, in essence, the so-called myths of the ancients were based on solid facts of observation and not, as has hitherto been supposed, on the imaginings of mythmakers.

\footnotetext{
${ }^{2}$ Euhemerus (circa second half of the fourth century B.C.) attempted a rationalistic explanation of the mythology prevailing in his time. The theory he propounded, in his novel of travel, Sacred History, was simply an extension of the current skeptical-scientific attitude to matters which until that time had been accepted without question. That theory was that the gods were merely men who because of their great exploits or beneficence had been accorded divine honors. In Crete, coming upon the remains of a tomb bearing the name of Zeus, Euhemerus argued that even Zeus had probably been no more than a great conqueror, who died and was buried in Crete, and afterwards deified. This creditable anthropological attempt to historicize mythology, though it failed to convince, is nevertheless worthy of great respect. As A. B. Cook wrote, if Euhemerus said that Zeus was a Cretan king when he ought to have said that Cretan kings played the part of Zeus, it is a pardonable error. (Zeus, I, 662.)
} 
Let us begin with a brief account of the most recent and most thoroughly documented story of a free-dwelling dolphin's social interaction with human beings. This is the story of Opo, a female Tursiops that made its appearance early in 1955 at Opononi, a small township just outside the mouth of Hokianga Harbour, on the western side of the North Island of New Zealand. From allowing itself at first to be rubbed with an oar or mop carried on the fishermen's launches, it began to glide in near the beach among the bathers. The cheerful putt-putt of a motor-launch or of an outboard motor was an irresistible attraction for Opo, and she would follow the boat like a dog, playing or cruising round it. If she had an urge to wander, starting up the motor would invariably draw her back again. Mr. Piwai Toi, a Maori farmer, who was the first to observe Opo, writes, "She was really and truly a children's playmate. Although she played with grownups she was really at her charming best with a crowd of children swimming and wading. I have seen her swimming amongst children almost begging to be petted. She had an uncanny knack of finding out those who were gentle among her young admirers, and keeping away from the rougher elements. If they were all gentle then she would give of her best." (Antony Alpers, The Dolphin, pp. 228-229.)

The child the dolphin favored was a thirteen-year-old girl named Jill Baker. At fourteen Jill wrote the following account of her experience with Opo:

"I think why the dolphin became so friendly with me was because I was always gentle with her and never rushed at her as so many bathers did. No matter how many went in the water playing with her, as soon as I went in for a swim she would leave all the others and go off side-by-side with me. I remember on one occasion I went for a swim much further up the beach than where she was playing, and I was only in the water a short while when she bobbed up just in front of my face and gave me such a fright. On several other occasions when I was standing 
in the water with my legs apart she would go between them and pick me up and carry me a short distance before dropping me again. At first she didn't like the feel of my hands and would dart away, but after a while when she realized I would not harm her she would come up to me to be rubbed and patted. She would quite often let me put little children on her back for a moment or two." (In Antony Alpers, The Dolphin, p. 229.)

Opo's choice of the gentle Jill Baker for the rides which she gave this thirteen-year-old, suggests not only a sensitive discrimination of the qualities of human beings, but also that the reports of similar incidents which have come down to us from antiquity were based on similarly observed events. The one element in these stories which seemed most difficult to accept, and which is so often represented in ancient art, the boy riding on the back of a dolphin, is now removed from the realm of fancy and placed squarely in the realm of fact. It has been corroborated and sustained.

Mr. Antony Alpers in his book on the dolphin, and especially that part devoted to the eyewitness accounts of Opo's behavior, goes far toward establishing the fact of the dolphin's remarkable capacity for rapport with human beings. But for those striking facts I must recommend you to Mr. Alper's charming book.

The dolphin's extraordinary interest in and, what we will I am sure not be far wrong in interpreting as, concern for human beings, is dramatically told by George Llano in his report Airmen Against the Sea. This report, written on survival at sea during the Second World War, records the experience of six American airmen, shot down over the Pacific, who found themselves in a seven-man raft being pushed by a porpoise toward land. Unfortunately the land was an island held by the Japanese. The friendly porpoise must have been surprised and hurt when he found himself being dissuaded from his pushing by being beaten off with the oars of the airmen.

Dr. Llano also reports that "Most observers noted that when 
porpoises appeared sharks disappeared, and they frequently refer to the "welcome' appearance of porpoises, whose company they preferred to that of sharks." This confirms all earlier reports that sharks are no match for the dolphin kind.

Dolphins have been known to push a mattress quite empty of human beings for considerable distances at sea. Possibly it is merely the pushing that interests them, and not the saving of any human beings that might be atop of them.

Is there any evidence that dolphins save drowning swimmers? There is.

In 1945 the wife of a well-known trial attorney residing in Florida was saved from drowning by a dolphin. ${ }^{3}$ This woman had stepped into a sea with a strong undertow and was immediately dragged under. Just before losing consciousness, she remembers hoping that someone would push her ashore. "With that, someone gave me a tremendous shove, and I landed on the beach, face down, too exhausted to turn over ... when I did, no one was near, but in the water almost eighteen feet out a porpoise was leaping around, and a few feet beyond him another large fish was also leaping."

In this case the porpoise was almost certainly a dolphin and the large fish a fishtail shark. A man who had observed the events from the other side of a fence told the rescued woman that this was the second time he had seen a drowning person saved by a "porpoise."

More recently, on the night of February 29, 1960, Mrs. Yvonne M. Bliss of Stuart fell from a boat off the east coast of Grand Bahama Island in the West Indies. "After floating, swimming, shedding more clothing for what seemed an eternity, I saw a form in the water to the left of me.... It touched the side of my hip and, thinking it must be a shark, I moved over to the right to try to get away from it.... This change in my position

\footnotetext{
3 “"Saved by a Porpoise," Natural History, LVIII (I 949), 385-386.

${ }^{4}$ Winthrop N. Kellogg, Porpoises and Sonar, University of Chicago Press, 1962, p. 14.
} 
was to my advantage as heretofore I was bucking a cross tide and the waves would wash over my head and I would swallow a great deal of water. This sea animal which I knew by this time must be a porpoise had guided me so that I was being carried with the tide.

"After another eternity and being thankful that my friend was keeping away the sharks and barracuda for which these waters are famous, the porpoise moved back of me and came around to my right side. I moved over to give room to my companion and later knew that had not the porpoise done this, I would have been going downstream to deeper and faster moving waters. The porpoise had guided me to the section where the water was the most shallow.

"Shortly I touched what felt like fish netting to my feet. It was seaweed and under that the glorious and most welcome bottom.

"As I turned toward shore, stumbling, losing balance, and saying a prayer of thanks, my rescuer took off like a streak on down the channel."

The reader must be left to make what he can of such occurrences. Dr. George G. Goodwin of the American Museum of Natural History doubts the intention of dolphins to save drowning persons. "Anything floating," he writes, "on or near the surface of the sea will attract his attention. His first action on approaching the object of his curiosity is to roll under it. In doing so, something partly submerged, like the body of a drowning person, is nudged to the surface of the water. The sea does its part and automatically drives floating objects toward the beach." This may well be so in some cases, but it is an explanation which does not fit the incidents described by Mrs. Bliss, in which she was not pushed but guided. Occam's razor should not be too bluntly applied.

\footnotetext{
${ }^{5}$ George G. Goodwin, "Porpoise-Friend of Man?" Natural History, LVI (1947), 337.
} 
The cooperativeness of dolphins with fishermen in various parts of the world has gone on for several thousand years without its significance having registered much upon the consciousness of the rest of the world-including the learned and the scientific.

In the Mediterranean from the earliest days, as recorded by Aelian in his On the Characteristics of Animals, VI, 15, to the present day, torchlight fishing with the aid of dolphins has been a traditional way of fishing. This has been described by Nicholas Apostolides in his book La Pêche en Grèce, who tells how fishermen of the Sporades catch their garfish "in the darkest nights of the month of October" by methods very similar to those described by Aelian. Briefly, the fish attracted by the fishermen's flares begin to collect, whereupon the dolphins appear and drive them into the fishermen's nets.

Similar methods of fishing were practiced in the Antipodes, off the New Zealand and Queensland coasts. The aborigines of Moreton Bay, Queensland, used to catch mullet with the aid of dolphins, at a place appropriately enough called Amity Point. The aborigines recognized individual dolphins and called them by name. With their nets ready on the beach the aborigines waited for a shoal of fish to appear, whereupon they would run down and make a peculiar splashing in the water with their spears, and the dolphins on the outside of the shoal would drive the fish towards the nets for the aborigines to catch. Fairholme, who described these events in 1856 , writes, "For my part I cannot doubt that the understanding is real, and that the natives know these porpoises [actually the dolphin Tursiops catalania], and that strange porpoises would not show so little fear of the natives. The oldest men of the tribe say that the same kind of fishing has always been carried on as long as they can remember. Porpoises abound in the bay, but in no other part do the natives fish with their assistance."

The Irrawaddy River dolphin is also an assistant-fisherman. 
John Anderson reports that "The fishermen believe that the dolphin purposely draws fish to their nets, and each fishing village has its particular guardian dolphin which receives a name common to all the fellows of his school; and it is this superstition which makes it so difficult to obtain specimens of this Cetacean. Colonel Sladen has told me that suits are not infrequently brought into the native courts to recover a share in the capture of fish, in which a plaintiff's dolphin has been held to fill the nets of rival fishermen." (John Anderson, Account of the Zoological Results of Two Expeditions to Western Yunnan.)

The Pink-Bellied river dolphin (Inia geoffrensis) of the Trapajós, a tributary of the Amazon, also helps its human friends with fishing. Dr. F. Bruce Lamb says that this dolphin, locally known as the boto, "is reported to have saved the lives of helpless persons whose boats have capsized, by pushing them ashore. None of the dreaded flesh-eating piranhas appear when a porpoise is present, for they themselves would be eaten." And he goes on to give an eye-witness account of fishing with the aid of a trained dolphin. "My curiosity was aroused," he writes, "by the paddler, who began tapping on the side of the canoe with his paddle between strokes and whistling a peculiar call. Asking Rymundo about this, he startled me by casually remarking that they were calling their boto, their porpoise.... As we approached the fishing grounds near the riverbank, Rymundo lit his carbide miner's lamp, adjusted the reflector, chose his first harpoon, and stood up in the bow ready for action. Almost immediately on the offshore side of the canoe about 50 feet from us we heard a porpoise come up to blow and take in fresh air." The porpoise then chased the fish toward the canoe and Rymundo harpooned them with ease.

Many ancient writers have referred to the brilliancy of the changeful colors when the dolphin is dying. Byron makes reference to this in "Childe Harold's Pilgrimage,"

${ }^{6}$ F. Bruce Lamb, "The Fisherman's Porpoise," Natural History, LXIII (1954), 231-2. 
Dies like the dolphin, whom each pang imbues

With a new colour as it gasps away;

The last still loveliest, till 'tis gone, and

all is gray."

Here is a peculiar confusion, for this is not the mammalian dolphin of which we have been speaking, but the swift piscivorous oceanic fish Coryphaena hippurus, the dolphin of sailors. It is blue with deeper spots, and gleaming with gold. It is, indeed, famous for the beauty of its changing colors when dying. The mammalian dolphin exhibits no such spectacular color changes when dying.

Happily, it is not with dying dolphins or with their changing colors that we are concerned here, but rather with ours, the changing color of the complexion of our once too sophisticated beliefs. Beliefs which, in their own way, were very much more in the nature of myths than the ancient ones which we wrote off a little too disdainfully as such. The history of the dolphin constitutes an illuminating example of the eclipse of knowledge once possessed by the learned, but which was virtually completely relegated to the outermost fringes of mythology during the last eighteen hundred years. Perhaps there is a moral to be drawn here. If so, I shall leave it to others to draw. But now that scientific interest in the dolphin has been aroused we are entering into a new era of delphinology, and with the confirmation of so many of the observations of the ancients already made, we may look forward with confidence to others. Dolphins have large brains; possibly they will some day be able to teach us what brains are really for. 


\section{Appendix A}

\section{A Note for Bibliophiles}

It was an ancient belief, as Camerarius tells us, that "when tempests arise, and seamen cast their anchor, the dolphin, from its love to man, twines itself round it, so that it may more safely lay hold of the ground." I know of no verifying evidence for this statement, but should not be surprised to find some element of truth in it. The dolphin twined about an anchor is the device which Aldus Manutius (1450-1515) adopted for his Aldine Press, which began publication in I494. This device was later adapted to his own use by the English publisher William Pickering (1796-1854).

The representation of the dolphin twined about the anchor refers to no maritime supremacy of that creature, but rather to its kindly regard for man. The following poem in George Wither's $A$ Collection of Emblemes ( 1635 ), throws some additional light on the meaning of the emblem.

If Safely, thou desire to goe,

Bee nor too Swift, nor overslow.

[Emblem]

[Dolphin and Anchor]

Illvstr. X. Book 2.

Our Elders, when their meaning was to shew

A native-speedinesse (in Emblem wise)

The picture of a Dolphin-Fish they drew;

Which, through the waters, with great swiftnesse, flies.

An Anchor, they did figure, to declare

Hope, stayednesse, or a grave-deliberation:

And therefore when those two, united are,

Its giveth us a two-fold Intimation.

For, as the Dolphin putteth us in minde,

That in the Courses, which we have to make, 
Wee should not be, to slothfulnesse enclin'd;

But, swift to follow what we undertake:

So, by an Anchor added thereunto,

Inform'd wee are, that, to maintaine our speed,

Hope, must bee joyn'd therewith (in all we doe)

If wee will undiscouraged proceed.

It sheweth (also) that, our speedinesse,

Must have some staydnesse; lest, when wee suppose

To prosecute our aymes with good successe,

Wee may, by Rashnesse, good endeavors lose.

They worke, with most securitie, that know

The Times, and best Occasions of delay;

When, likewise, to be neither swift, nor slow;

And, when to practise all the speed, they may.

For, whether calme, or stormie-passages,

(Through this life's Ocean) shall their Bark attend;

This double Vertue, will procure their ease:

And, them, in all necessities, befriend.

By Speedinesse, our works are timely wrought;

By Staydnesse, they, to passe are, safely, brought.

From A Collection of Emblemes, Ancient and Moderne, by George Wither. London, 1635 . Book 2, p. 72. 


\section{Appendix B}

\section{Dolphins and Their Distribution}

Order: CETACEA

Suborder: ODONTOCETI

Family: Delphinidae

Subfamily: Delphininae

Genus: Delphinus

Subfamily: Delphinapterinae

Genus: Monodon

Genus: Delphinapterus

The Suborder Odontoceti of the Order Cetacea consists of the toothed whales, in contrast to the toothless whalebone or baleen whales, the Mystacoceti. The whales are large dolphins or one may say that dolphins are small whales. The members of the Odontoceti are the Dolphin, Freshwater Dolphin, Porpoise, Sperm Whale or Cachalot, Lesser Sperm Whale, Bottle-Nose Whale, Narwhal or Sea-Unicorn, White Whale, Pilot Whale or Black-Fish, Killer Whale or Grampus.

Delphinus delphis: The Common Dolphin. It is easily recognized by its well-defined narrow beak and distinctive coloration, being darker above than below. There is a narrow beak, which is sharply marked off from the low reclining forehead by a V-shaped groove. A length of up to $81 / 2$ feet has been recorded. Range of distribution is very wide. May be met in any temperate or warm sea throughout the world, and occurs at times in vast schools.

Delphinus roseiventris: The Red-Bellied Dolphin. Moluccas and Torres Straits, Australia; 3 feet ro inches.

Prodelphinus attenuatus: Tropical and sub-tropical parts of Atlantic Ocean; 6 feet.

P. plagiodon: Atlantic coast of North America from Cape Hatteras, Gulf of Mexico; 7 feet. 
P. froenatus: The Bridled Dolphin. Atlantic and Indian Oceans; about 6 feet.

P. malayanus: East Indies; more than 6 feet.

P. coeruleoalbus: South America, near mouth of River Plate; about 4 feet.

P. euphrosyne: Atlantic Ocean to South Africa; about 8 feet.

Genus Tursiops

T. truncatus: The Bottle-Nosed Dolphin. Has a short well-defined snout 2 or 3 inches long. There is a prominent fin in the middle of the back. Reaches a length of I I to 12 feet. Has a very wide range. Commonest along the Atlantic coast of America from Maine to Florida. Found in Bay of Biscay, in the Mediterranean Sea, and in New Zealand waters.

T. abusalam: Red Sea; 6 feet.

T. catalania: Indian and Australian seas.

Genus Steno

S. rostratus: The Rough-Toothed Dolphin. Long-beaked, with roughened or furrowed teeth. Atlantic and Indian Oceans; about 8 feet.

\section{Genus Orcaella}

O. brevirostris: Irrawaddy River Dolphin. From Bay of Bengal, Vizagapatam, Singapore, and Siam (i.e., S.E. Asia).

Genus Lissodelphis or Tursio

Lissodelphis: The Right Whale Dolphin. All oceans.

Genus Grampus

G. griseus: Risso's Dolphin. North Atlantic, Mediterranean, New Zealand, and Cape of Good Hope; I2 to I3 feet.

Genus Cephalorhynchus

These are the Southern, mostly cold-water dolphins.

C. heavisidei: Heaviside's Dolphin. Cape of Good Hope; about 4 feet.

C. hectori: Hector's Dolphin. New Zealand; about 6 feet.

C. albiventris: White-Bellied Dolphin. A very rare form, found off the coast of South America; about 4 feet 6 inches.

C.commersonii: Commerson's Dolphin; also known as the Piebald Porpoise or Le Jacobite. Southern oceans; up to $5 \frac{1}{4}$ feet. 


\section{Genus Lagenorhynchus}

Characterized by great number of vertebrae ( 80 to 90), great length of transverse and vertical bony processes from vertebrae, moderately pointed high back fin having concave posterior border; the beak is short.

L. acutus: The White-Sided Dolphin. North Atlantic; about 9 feet.

L. australis: Peale's Porpoise. Cape Horn, Chile, Patagonia, Falkland Islands; over 7 feet.

L. albirostris: The White-Beaked Dolphin. North Atlantic; 9 to Io feet.

L. cruciger: South Pacific; 5 to 6 feet.

L. fitzroyi: Fitzroy's Dolphin. Southern end of South America; 5 feet 4 inches.

L. obscurus: Dusky Dolphin. South Africa, New Zealand, Falkland Islands; 7 feet.

\section{Genus Sotalia}

Concentrated in the tropical seas or rivers of South America, Africa, India, and the Far East.

S. pallida: Buffeo blanco. Upper Amazon; 5 feet 6 inches.

S. fluviatalis: Buffeo negro. Upper Amazon; 3 feet 7 inches.

S. tucuxi: Upper Amazon.

S. guianensis: N. E. coast of South America.

S. teuszii: Noteworthy as being the one Cetacean believed to feed exclusively on vegetable matter. Kamerun River.

S. gadamu: Vizagapatam; averages 7 feet; snout 6 inches.

S. lentiginosa: Vizagapatam.

S. plumbea: Malabar coast of India; about 8 feet; very long snout.

S. borneensis: Gulf of Siam to Sarawak in Borneo.

S. sinensis: Chinese White Dolphin.

The Fresh Water Dolphins.

\section{Genus Platanista}

P. gangetica: The Susu or Gangetic Dolphin; about 8 feet; snout and beak drawn into long forceps-like beak, 7 or 8 inches long; confined to River Ganges and River Indus. It is almost blind. 
Genus Inia

I. geoffrensis: Amazonian Dolphin or Boutu. Upper Amazon; 7 feet; long beak.

Genus Pontoporia

P. blainvillei: La Plata Dolphin. Estuary of Rio de la Plata; about 5 feet.

\section{Genus Lipotes}

L. vexillifer: Chinese River Dolphin. Ting Ling Lake, 600 miles up the Yang-tse River; 7 feet 6 inches; slightly upcurved jaws.

\section{The Porpoise}

The small beakless Delphinidae, which have a triangular dorsal fin and spade-shaped teeth, black above and white below; travels in large schools. The word "porpoise" is derived from the French porcpoisson, "pig-fish." Never larger than 6 feet.

Genus Phocaena

P. phocaena: The Common Porpoise. Chiefly North Atlantic and North Pacific; never larger than 6 feet.

P. spinipinnis: Burmeister's Porpoise. Rare. La Plata round Horn to Peru.

P. dalli: Dall's Harbor Porpoise. Very rare. Alaska; less than 5 feet.

P.truei: True's Porpoise. Japan; less than 5 feet.

P. dioprica: River Plate to South Georgia.

Genus Neomeris

N. phocaenoides: Finless Black Porpoise. Cape of Good Hope to Japan.

Genus Lissodelphis

L. peronii: New Zealand and Tasmania; about 6 feet.

L. brealis: North Pacific; about 8 feet.

The Right Whale Dolphins

\section{The Whales with Teeth}

The toothed whales are big dolphins, and are on the average much smaller than the Whalebone or Baleen toothless Whales.

Family Physeteridae

Subfamily Physeterinae 


\section{Genus Physeter}

P. catodon: The Sperm Whale or Cachalot. All oceans. Male may reach 60 feet, the female usually half the length of the male. This is the whale that has suffered the relentless persecution of whalers, always a coveted prize on account of its spermaceti-permeated blubber, and its excretory ambergris. The most dangerous of whales.

Subfamily Kogiinae

\section{Genus Kogia}

K. breviceps: The Pigmy or Lesser Sperm Whale. Atlantic, Pacific, Indian, and Antarctic oceans; about ro feet.

Family Ziphiidae

Genus: Hyperoödon rostratus: The Bottle-Nose Whale. North Atlantic, Mediterranean, South Pacific, and Antarctic; 20 to 30 feet.

Genus: Mesoplodon: "The Cow Fish;" Atlantic, Pacific, and Indian oceans.

Genus: Ziphius: The Two-Toothed Whale. All oceans.

Genus: Tasmacetus: South Pacific.

Genus: Berardius: Pacific.

Family Monodontidae or Delphinapteridae

\section{Subfamily Delphinapterinae}

Genus: Monodon monocerus: Narwhal or Sea Unicorn. Arctic seas south of the ice-field. The male is characterized by an immense tusk, sometimes 9 feet long, projecting like a spear from the left side of the bluntly-rounded muzzle. The tusk is spirally grooved, and is the source of the horn of the unicorn of heraldry. Mottled in color, and about $\mathrm{I} 8$ feet long.

Genus: Delphinapterus leucas: The White Whale or Beluga. Resembles the Narwhal in size, shape, and habitat, but the tusk is absent.

Family Delphinidae

\section{Genus Globiocephala}

G. melas: Pilot Whale or Black-Fish or Ca'ing Whale. Temperate or tropical seas. Rounded head with dorsal fin. Takes its name from the fact that one whale or pilot leads the way of the sometimes huge schools; about 25 feet. 
Genus Orcinus

O. orca: Killer Whale or Grampus. All seas. With a high dorsal fin and black and white coloring, aggressively bold and carnivorous, with singular cunning and intelligence. Fourteen seals and thirteen porpoises have been found in the stomach of a male measuring $2 \mathrm{I}$ feet. The male is usually about 30 feet in length.

Genus Psendorca

P. crassidens: The False Killer Whale or Lesser Killer Whale. All seas.

\section{REFERENCES}

Aelian. On the Characteristics of Animals. Bk. VI, I5. Aesop. Fables. "The Monkey and the Dolphin."

Alpers, Antony. Dolphins: the Myth and the Mammal. Boston: Houghton Mifflin, I96r.

Anderson, John. Anatomical and Zoological Researches: Comprising an Account of the Zoological Results of the Two Expeditions to Western Yunnan. London: Bernard Quaritch, I878.

Apollodorus. The Library. III, 5, 3 .

Apostolides, Nicholas. La Pêche en Grèce. Athens, 1907.

Aristotle. History of Animals. Bk. I, 5; II, I, 13, I5; III, I, 7, 20; IV, 8-10; V, 5; VI, I2; VIII, 2, I3; IX, 48.

Biedermann, Paul. Der Delphin in der dichtenden und bildenden Phantasie der Griechen und Roemer. Halle, r88I.

Cook, Arthur B. Zens: A Study in Ancient Religion. Cambridge, Eng.: The University Press, 19r4, vol. I, p. 662.

Douglas, Norman. Birds and Beasts of the Greek Anthology. London: Chapman and Hall, 1928, p. I6r.

Euhemerus. Sacred History.

Fairholme, J. K. E. "The Blacks of Moreton Bay, and the Porpoises," Proceedings of the Zoological Society of London, XXIV (1856), 353-354.

Goodwin, George G. "Porpoise-Friend of Man?" Natural History, LVI (1947), 337.

The Greek Anthology.

Herodotos. History. Clio I, 23-24. 
Hill, Ralph N. Window in the Sea. New York: Rinehart, 1956.

Kellogg, Winthrop N. Porpoises and Sonar. Chicago: University of Chicago Press, 196r.

Klement, Carl. Arion. Vienna, 1898.

Lamb, F. Bruce. "The Fisherman's Porpoise," Natural History, LXIII (1954), 23I-232.

Llano, George A. Airmen Against the Sea. Maxwell Air Force Base, Alabama; Arctic, Desert, Tropic Information Center [1955 or $1956]$, p. 74 .

Longman, Heber. "New Records of Cetacea," Memoirs of the Queensland Museum, VIII (1926), 266-278.

Longus, Cornificius. De Etymis Deorum.

Lucian. Marine Dialogues. 8.

Lycophron. Alexandra.

Nonnus Panopolitanus. Dionysiaca. VI, 265-266.

Norman, John R., and Fraser, F. C. Giant Fishes, Whales, and Dolphins. London: Putnam, 1937.

Oppian. Halieutica. I, 649-654, 1089; V, 422, 519f.

Ovid. Metamorphoses. III, I, 202.

Pliny the Elder. Natural History. IX, 8, 24-28.

Pliny the Younger. Letters. IX, 23.

Plutarch. On the Cleverness of Animals.

Porphyry. De Abstinentia. III, I6.

Rabinovitch, Melitta. Der Delphin in Sage und Mythos der Griechen. Dornach: Hybernia-Verlag, 1947.

"Saved by a Porpoise," Natural History, LVIII (1949), 385-386.

Schmidt, Bernhard. Das Volksleben der Neugriechen. Leipzig, I87ı.

Servius. Commentarii in Vergilii Aeneidos. III, 332.

Stebbins, Eunice B. The Dolphin in the Literature and Art of Greece and Rome. Menasha, Wisconsin: Banta Publishing Co., 1929.

Usener, Hermann. Die Sintfluthsagen. Bonn: F. Cohen, I899.

Xenophon. Anabasis. V, 4, 28. 


\section{Modern Whales, Dolpbins, and Porpoises, as Challenges to Our Intelligence}

By JOHN C. LILLY

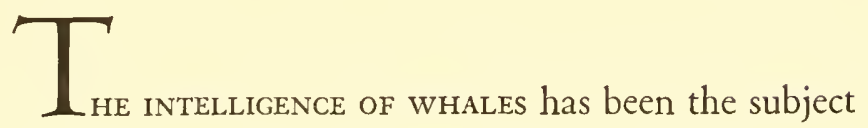
of speculation by writers since Ancient Greece., The discovery of the large brains of the Cetacea in the eighteenth century led to inevitable comparisons of these brains to those of the humans and of the lower primates. The winds of scholarly opinions concerning the whales have anciently blown strongly for high intelligence but during later centuries shifted strongly against high intelligence. At the time of Aristotle (384-322 B.C.) the dolphin, for example, was held in high esteem, and many stories of the apparently great abilities of these animals were current. ${ }^{2}$ By the time of Plinius Secundus (A.D. 23-79) the beginning of a note of skepticism was introduced. Plinius said, "I should be ashamed to tell the story were it not that it has been written about by ... others."1

In the middle ages the strong influence of religious philosophy on thinking placed Man in a completely separate compartment from all other living creatures, and the accurate anatomy of the 
whales was neglected. This point is illustrated by Figure r, published in the 1500's in Historia Animalium by Konrad Gesner. This was apparently a baleen whale. It has two tubes which apparently symbolize the double blowhole of the Mystacocetae. There is no modern whale known that has such tubes sticking out of the top of his head. There is a huge eye above the angle of the jaw. All whales have the eye at or near the posterior angle of the jaw. The eye is very much smaller than the one shown here. A print published in 1598 of the anatomy of these animals is shown in Figure 2. The drawing of the male organ is accurate (apparently it was measured with a walking stick), but the eye is too large and is misplaced.

These pictures illustrate very well man's most common relationship to the whale, which has continued to the present day. For commercial reasons man continues to exploit these creatures' bodies.

It was not until the anatomical work of Vesalius and others that the biological similarities and differences of man and other mammals were pointed out. It was at this time that the investigation of man's large and complex brain began.

All through these periods intelligence and the biological brain factors seemed to be completely separated in the minds of the scholars. At the times of the Greeks and the Romans there was little, if any, link made between brain and mind. Scholars attributed man's special achievements to other factors than excellence of brain structure and its use.

After the discovery of man's complicated and complex brain and the clinical correlation between brain injury and effects on man's performance, the brain and mental factors began to be related to one another. As descriptions of man's brain became more and more exact and clinical correlations increased sufficiently in numbers, new investigations on the relationships between brain size and intelligence in Homo sapiens were started. The early work is summarized by Donaldson. ${ }^{3}$ 
In the late I700's and the early I80o's the expansion of the whaling industry offered many opportunities for examination of these interesting mammals. Figures 3 and 4 are dramatic examples of the state of the industry in the late eighteenth and early nineteenth centuries.

One of the earliest drawings of the complex brain of one of the cetacea is that of Gottfried Reinhold Trediramus in 1818 (Fig. 5). This is an anterior view of the brain of the common porpoise Phocaena phocaena. This is one of the earliest pictures showing the complexity of the fissuration and the large numbers of gyri and sulci.

By the year 1843 the size of the brain of whales was being related to the total size of the body. The very large brains of the large whales were reduced in importance by considering their weight in a ratio to the weight of the total body. This type of reasoning was culminated with a long series of quantitative measures published by Eugène Dubois (Bulletins de la Société d'Anthropologie de Paris, Ser. 4, VIII [1897], 337-376).

Descriptions from those of Hunter and Tyson onwards agree that, in absolute size, the brains are as large and larger than those of man. All were agreed that the smaller whales, i.e., the dolphins and porpoises, have very large brains with relation to their body size. It was argued, therefore, with respect to the dolphin, "this creature is of more than ordinary wit and capacity." (Robert Hamilton, The Natural History of the Ordinary Cetacea or Whales, p. 66, in Sir William Jardine, The Naturalist's Library, volume 7, Edinburgh, I843.)

Tiedemann's drawings of the brain of Delphinus delphis and of Delphinus phocaena were published by H. G. L. Reichenbach in his Anatomia Mammalium in $\mathbf{1} 845$. The four drawings are shown in Figure 6. These drawings show the improved awareness of the complexities of these large brains in regard to cerebral cortex, the cerebellum, and the cranial nerves. Correlations between the structure of this brain and the behavior of the 
animal possessing it, were (and are) woefully lacking. The only behavioral accounts were those of whalers hunting these animals. Hunters tend to concentrate on the offensive and defensive maneuvers of the animal, and can give useful information for other kinds of evaluation of the animal's behavior and presumed intelligence.

In 1787 John Hunter, writing in the Philosophical Transactions of the Royal Society of London (LXXVII, 423-424), said the following: "The size of the Brain differs much in different genera of this tribe, and likewise in the proportion it bears to the bulk of the animal. In the Porpoise, I believe, it [the proportion] is largest, and perhaps in that respect comes nearest to the human...

"The brain is composed of cortical and medullary substances, very distinctly marked; the cortical being, in colour, like the tubular substance of a kidney; the medullary, very white. These substances are nearly in the same proportion as in the human brain ... The thalami themselves are large; the corpora striata small; the crura of the fornix are continued along the windings of the ventricles, much as in the human subject."

Flatau and Jacobsohn in 1899 wrote, "the large brain of the Porpoise is one of the smallest in the Cetacean Order in which the organ attains to a much greater absolute size than any other."

In I902 G. Elliot Smith wrote of the brain of a species of dolphin called "Delphinus tursio" (which may be the modern Tursiops truncatus): "This brain is larger and correspondingly richer in sulci than that of the porpoise: but the structure of the two organs is essentially the same." His drawings are shown in Figures 7 and 8. He said further, "the brains of the Beluga and all the dolphins closely resemble that of the porpoise."

Smith summarizes the discussion of the huge size of the whale's brain. "The apparently extraordinary dimensions of the whale's brain cannot therefore be considered unusual phe- 
nomena, because this enormous extent of the cerebral cortex to receive and 'store' impressions of such vast sensory surfaces becomes a condition of survival of the animal.

"The marvelous complexity of the surface of the cerebrum is the direct result of its great size. In order, apparently, that the cerebral cortex may be efficiently nourished and at the same time be spared to as great a degree as possible the risk of vascular disturbances [such as would be produced by large vessels passing into it], its thickness does not appreciably increase in large animals. [He then quotes Dubois' figures showing that the whale's cortex is the same thickness as that of the human.] Such being the case, it naturally results that the increased bulk of cortex in large animals can only be packed by becoming thrown into increasing number of folds, separated by corresponding large number of sulci."

In regard to communication between individual whales, Scammon in 1874 wrote the following: "It is said that the Cachalots [Sperm Whales] are endowed with the faculty of communicating with each other in times of danger, when miles ... distant. If this be true, the mode of communication rests instinctively within their own contracted brains. ${ }^{, 5}$ Let us not forget that Scammon was talking about the mammal with the largest known brain on this planet. Instinct as the sole cause of communication with a brain this size seems rather improbable. This brain is not any longer considered "contracted." Both of these statements illustrate an authoritative view of that time. If one peruses the paper by Tokuzo Kojima, "On the Brain of the Sperm Whale" (in the Scientific Reports of the Whales Research Institute, Tokyo, VI, I95I, 49-72), one can obtain a modern clear view of this brain. The largest one that he obtained (from a 49-foot sperm whale) was 9,200 grams. The average weight of the sixteen brains presented in his paper is 7,800 grams for average body lengths of 50 feet. (The brain weight per foot of body length varied from II 8 to I 87 grams 
per foot, averaging 157; man's ratio averages about 250 grams per foot.)

In the literature of the time of Scammon, the scholars failed to give us new information about the behavior of cetacea. There seems to have been a distinctly ambivalent attitude towards these animals which is continued today. This point of view can be summarized as follows: the whale is a very large animal with a brain larger than that of man. This brain is the result of the huge growth of its body. All of this large brain is needed to control a large body. Because these tasks are so demanding, there is not enough brain substance left for a high degree of intelligence to develop. Thus the large brain cannot give the degree of intellectual capability that man has.

As an example of man's attitudes to cetaceans, consider the case of the U. S. Fisheries Bureau Economic Circular No. 38, of November 6, I918, by Lewis Radcliffe, entitled "Whales and Porpoises as Food." Roy Chapman Andrews is quoted as saying that hump-backed whale meat is the best of the larger cetaceans but that porpoise and dolphin meat is even better eating than that of the larger whale. The composition of the whale meat is given as $30 \%$ protein, $6 \%$ fat, and less than $2 \%$ ash. From a hump-back whale one obtains six tons of meat, from a Sei Whale, five tons, and from a Finback, eight tons. Directions are given to remove the connective tissue between the blubber and the muscle to avoid the oily taste. For those who are interested, the paper includes twenty-two whale meat recipes and ten porpoise meat recipes.

It can well be imagined, if we ever do communicate with whales, dolphins, or porpoises, the kind of reception that this sort of literature will receive from the cetaceans.

The limited point of view of the whales as "dumb beasts" neglects the adaptations that have taken place in non-mammalian forms with very much smaller brains but with comparable bulk of body. The 6o-foot whale shark, a plankton eater, 
and like the rest of the sharks a water-breather, has a bulk of body comparable to that of the larger whales. It has a large brain cavity but a very small brain in a small part of this large cavity. (It is very difficult to find the weight of these brains to compare with that of the cetacea and other mammals.) The problem of brain weight versus body weight versus intelligence is most clearly expressed by Gerhardt von Bonin in his paper in the Journal of General Psychology (1937). ${ }^{8}$ He gives a very extensive table for mammals, their brain weight, their body weight, and the values of 2 parameters for their specification. He then states, "it is clear from all that has been said above that the figures given here are nothing but a description of facts, a description which, in the mathematical sense of the term, is the 'best' one. It does not pretend to make any enunciation about the relation of intelligence and brain weight. For that purpose we need a much broader psychological basis than we have at present.

"Former attempts to analyze the relations between body weight and brain weight suffer from three deficits: (I) they presuppose a correlation between intelligence and brain weight, (2) they make suppositions about the intelligence of animals which are unproven, and (3) they are based on a conception of cortical function which can no longer be considered valid ... There is a close correlation between the logarithms of brain and body weight, and this co-relation is linear. Brain weight increases as the 0.655 th power of body weight. The value of the cephalization co-efficient $\mathrm{k}$ differs from species to species. Whether or not this is an indication of the intelligence of animals must be left to the psychologists to answer."

One of the problems that the whales have, as compared to, say, the large shark, is breathing air while living in the sea. This requires that these animals reach the air-water interface relatively frequently-at least every one hour and a half for the bottlenose whale (Hyperoodon), three-quarters of an hour for 
the Sperm Whale (Physeter catadon), and every six minutes for Tursiops truncatus. This puts very stringent requirements on the relationship of the whales to other events within the sea. Each whale must know where the surface of the sea is at each instant and compute his future actions so that when he does run out of air he is near the surface. He is essentially a surface-to-depth and depth-to-surface oriented animal. He must travel at high speed at times in order to recapture enough air to continue whatever he is doing under the surface. This means that he must calculate his chances of obtaining a good breath of air during rain storms and similar situations. He can be violently thrown around at the surface unless he comes up in the trough rather than at the crest of the wave. Such calculations probably require an exercise of something more than just "instinct."

Water-breathing animals, on the other hand, have no need for such calculations. If the surface gets rough, they move downward and stay there. The required maneuvers are very much simpler and the amount of computation is very much less.

This requirement for the whales implies that the information coming from every one of the senses, not just the skin, needs to be correlated very rapidly and in complex patterning to allow the animals to predict their future course safely and accurately. It also requires the use of large amounts of information from memory.

The predators of the sea, other than the whales themselves, make life in the sea rather a complex business for mammals. The very large sharks can and do attack whales, dolphins, and porpoises. At times such attacks are by overwhelming numbers of sharks on a relatively small number of dolphins. All of the older animals in our experience have at least one shark bite on themthe younger animals are protected by the older ones and most of them are not so dramatically scarred.

The whales, in turn, must track their own prey in order to obtain food. With the single known exception of Orca, none of 
their predators are air-breathers. In general, the whales' diet consists of fish, squid, or other water-breathing organisms of the sea.

A scientific assessment of the position of these animals in the competitive environment of the sea is not yet fully evaluated quantitatively. Any pronouncement of the requirements in regard to new complex adaptations to new complicated situations and hence the evaluation of intelligence of these animals at this time is premature and presumptuous. The whole issue of the meaning and the use of these large brains is still very much unknown. As I say in Man and Dolphin," I am espousing a plea for an open-minded attitude with respect to these animals. It would be presumptuous to assume that we at the present time can know how to measure their intelligence or their intellectual capacity. The usual behavioral criteria used in evaluation of intelligence of other animals are obviously inapplicable to a mammal living in the sea. As McBride and $\mathrm{Hebb}^{8}$ so clearly stated, they cannot place the dolphin in any sort of intellectual comparative intelligence scale; they did not know the appropriate experimental questions to ask in order to compare the dolphins with the chimpanzees, for example. Comparing a handedmammal with a flippered-mammal, each of which lives in an entirely separate and distinctive environment, is a very difficult intellectual task even for Homo sapiens.

In pursuing possible measures of intellectual and intelligent capacity, what line should one pursue? I explored this question somewhat in Man and Dolphin, but wish to summarize and extend it here in this discussion. The invariants that we are seeking somehow do not seem to be as concrete as "tool-making and tool-using ability" by means of the hands which has been one of the major alleged criteria for human adaptation and success. The chimpanzee and the gorilla have the hands but they do not have the brains to back up the use of the hands. Man has both the hands and the brain. Thus we can quite simply and 
concretely contrast the performance of the large brains of man with his hands to the smaller brains of the primates with their hands. When we consider the whales, we seem obsessed, as it were, with the necessity of our own nature to look for an analog of the hand and the manipulative ability. May it not be better to find a more general principle than just handedness and its use?

I suggest that we think more in terms of a physiologically appropriate set of more general mechanisms which may subsume several other human functions under the same principle. It seems to me that we must look for abilities to develop generalized dexterity of use for certain kinds of end purposes for any or all muscular outputs from the central nervous system. If there is a task to be done, such as lifting a stone, whether in water or air, a given animal may turn it over with his foot, with his flipper, with his hand, with his tail, or with any other body part with which he could obtain a purchase on the stone. The end task is turning over the stone, to obtain food or whatever. It makes little difference what kind of muscular equipment he uses just so he uses it appropriately.

Let me illustrate with a more complex example seen in our own laboratory. A baby dolphin was being nursed in a small tank artificially. It apparently needed the constant attention of a human attendant. Its mother had not been caught with it. After several days it discovered that if it banged on the bottom of the tank with its flipper in a rhythmic fashion it could bring the humans from the other room. (We heard a loud thumping sound transmitted from a hydrophone in its tank.) Previous to this it attempted to bring the humans from the other room by whistling the distress call of the dolphins; unlike its mother, the humans did not respond to the whistle. In a sense this distress call is in his instinctual pattern for obtaining food and aid by other dolphins. The secondary adaptation and the new effort was that of manipulating the flipper rather than the phonation mechanism in the blowhole. Thus driven by whatever the in- 
stinctual need is, it tried different outputs from its brain and finally discovered one which brought the desired results. This ability to change the output from unsuccessful ones to successful ones seems to me to be evidence of a "higher nervous system" function. Of course in fine gradation and small differences, the same kind of pattern can be shown for smaller-brained animals. It is the seeking a new output, not necessarily instinctually tied in, and the radicalness of the change of output, plus the relating of many of the variables to one another thus generating the new output, that seems to be the hallmark of the large brain. These problems are not single variable ones with simple cause and effect, but are simultaneous multiple variable ones.

Among the manipulable outputs (muscular groups) I would include those of respiration and phonation. The dexterous and finely differentiated use of these muscles generates all the complexities of human speech. As more of the physiology and psychology of human speech are analyzed and made part of our sciences, the sharper will be our criteria for separating man from the other animals, and from those with smaller brains. Scientific descriptions of human speech are of relatively recent origin. Scientific descriptions of the physiology of the vocal tract are anything but a closed book at the present time. The neuroanatomy and neurophysiology of speech is in a relatively primitive state of development as a science. With such a lack of knowledge of the intimate and detailed mechanisms concerned, it would be rather presumptuous to evaluate at the present time their role in the measurement and testing of intelligence and intellectual capacity.

However, I wish to point out that these factors are important in such an evaluation and become even more important in terms of evaluating a species that is not human. Thus it is necessary, in order to evaluate the intelligence of even the dolphins, much less the whales, to know something of their abilities in the areas of phonation and other kinds of bodily gestures and manipula- 
tions and hence in their abilities to communicate with one another. As I implied in Man and Dolphin, it is not possible to measure accurately the intelligence of any other being than that of a human being, mainly because we do not exchange ideas through any known communication mode with such beings.

The difficulties of such understanding as we can possibly gain of the real situation of the whales in the sea and their adaptation as mammals to this particular environment, can be illustrated by their use of sonic generators for the location of their prey and of the boundaries of their container by means of the perception of echoes. As is well known, the small mammals, such as the bat, use this mechanism in air." The bottlenose dolphin also uses this same kind of mechanism underwater. ${ }^{7,0,10}$ Because these animals are immersed in a medium of a density and a sound velocity comparable to the density and sound velocity of their own bodies, they can presumably use their sonar also in looking, as it were, inside one another's body. The sonar view of the inside of the body of a dolphin may possibly be very instructive to other dolphins and possibly even aid in diagnosis of the causes of certain problems, especially of those of the baby by the mother. For example, their buoyancy depends upon maintaining their center of gravity below their center of buoyancy; otherwise they turn over and drown. If the baby develops gas in stomach \# $\mathrm{I}$, he can develop problems in his buoyancy relationship which turn him over; however, the mother dolphin can probably easily find out whether or not there is a bubble of gas in the baby's stomach by her echo ranging abilities. When she discovers such a bubble, she can then burp the baby by banging on the belly with her beak. We have seen such operations take place in our tanks. Here is another instance of the animal using a given output, coupled with the proper input, to diagnose a problem and to manipulate other outputs in the solution of that problem. How much of this is labeled "instinctual," i.e., "unlearned," is purely a matter of intellectual taste. 
In the sea it is necessary to use sonic mechanisms for sightings and recognition. If one goes into the sea one realizes that one's range of vision even under the best of circumstances is rarely beyond Ioo feet and most of the time is less than that even near the brilliantly lit surface of the tropical seas. With sonic means, one's range is extended up to several miles under the best of circumstances and under the worst to a few hundred feet.

Recently we have obtained evidence that shows that the dolphins communicate most of their information in the band of frequencies extending from about 8 kilocycles to 20 kilocycles by means of whistles and sonic clicks. ${ }^{11}$ However, as shown by Schevill and Lawrence, they can hear sounds at least to I2o kilocycles $^{12}$ and as shown by Kellogg can produce sounds at least to I70 kilocycles. ${ }^{10}$ We have recently been investigating the higher frequency bands in these animals and have reliable evidence that they can hear at least to 200 kilocycles and can produce sounds to at least 200 kilocycles. ${ }^{73}$ With the proper electronic equipment one can listen to the nearer portions of the upper band and quickly determine that they can transmit in these bands without the necessity of transmitting in the (lower frequency) communication band. The high frequency information is broadcast in a narrow beam off the front of the beak as was first detected by Kenneth Norris. ${ }^{14}$

In these bands we find that they can produce musical tones or individual clickings or hissing-like noises. Recently we have found that an emotionally upset animal threatens other animals and humans by productions of very large amounts of energy both in the sonic communication band and in the ultrasonic bands. Recently we have had the opportunity of working with an old bull of $45^{\circ}$ pounds weight who is so old his teeth have been ground down flat. In terms of his skeleton, he is the most massive animal we have ever seen. When he is irritated, his "barks" have sizable amounts of energy from about 0.5 to at least 300 kilocycles. He is also capable of transmitting in bands 
between 100 to 300 kilocycles without transmitting anything in the band from 8 kilocycles to 20 kilocycles in a narrow beam straight ahead of his body. When he is upset by the activities of a younger male, they face one another and blast at one another with short barks of this sort, meanwhile "threatening" by opening their mouths.

Since they live immersed in an acoustic world quite strange to us, we have great difficulty in appreciating the full life of these animals with respect to one another and their environment. From birth they are constantly bombarded with signals from the other animals of the same species and by echoes from the environment which they can apparently use very efficiently. Their ultrasonic (to us) emissions are not merely "sonar," but are interpersonal and even emotional. These animals are not inanimate, cold pieces of sonar apparatus. They use their ultrasounds and their high-pitched sounds interpersonally with fervor in everything they do. ${ }^{15}$

We have demonstrated that the dolphins are quite capable of using vocal outputs as a demand for further rewards or for surcease from punishment. Their ability in the vocal sphere is quite sophisticated. In addition to the ultrasonic matters mentioned above, their sonic performance, when in close contact with man, is astonishing. In 1957 I discovered their ability to produce sounds similar to our speech sounds. ${ }^{10}$ During the last two years we have had many opportunities to pursue further observations in this area. This emerging ability seems to be an adaptation to a new environment which includes Man. ${ }^{17}$ They quickly discover that they can obtain various kinds of rewards by making what we now call "humanoid emissions." When they make a sound which sounds similar to a human syllable or word, we express our pleasure by rewarding the animals in various ways. We have been exploring what some of these rewards are in order to elicit further such behavior under better control. 

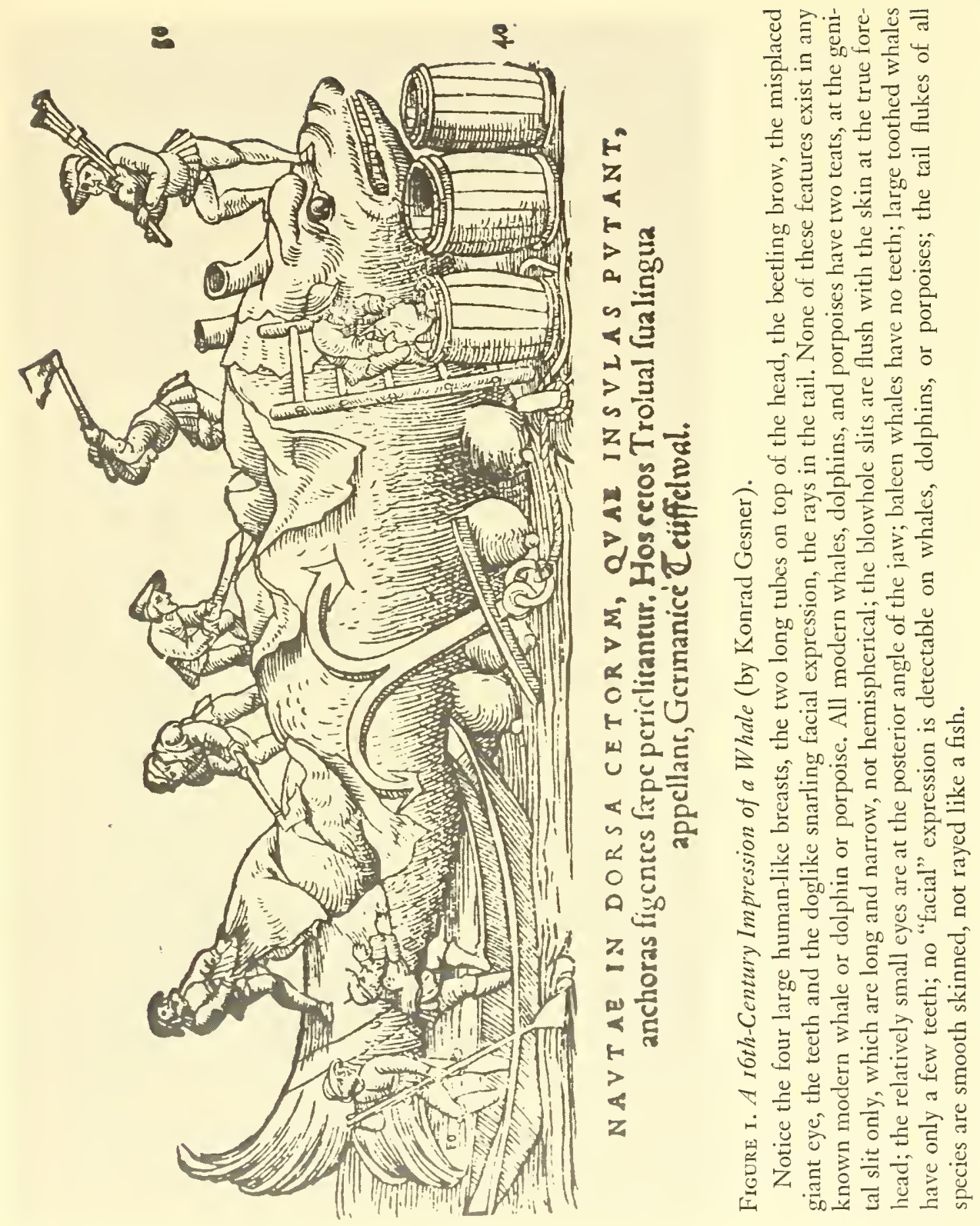


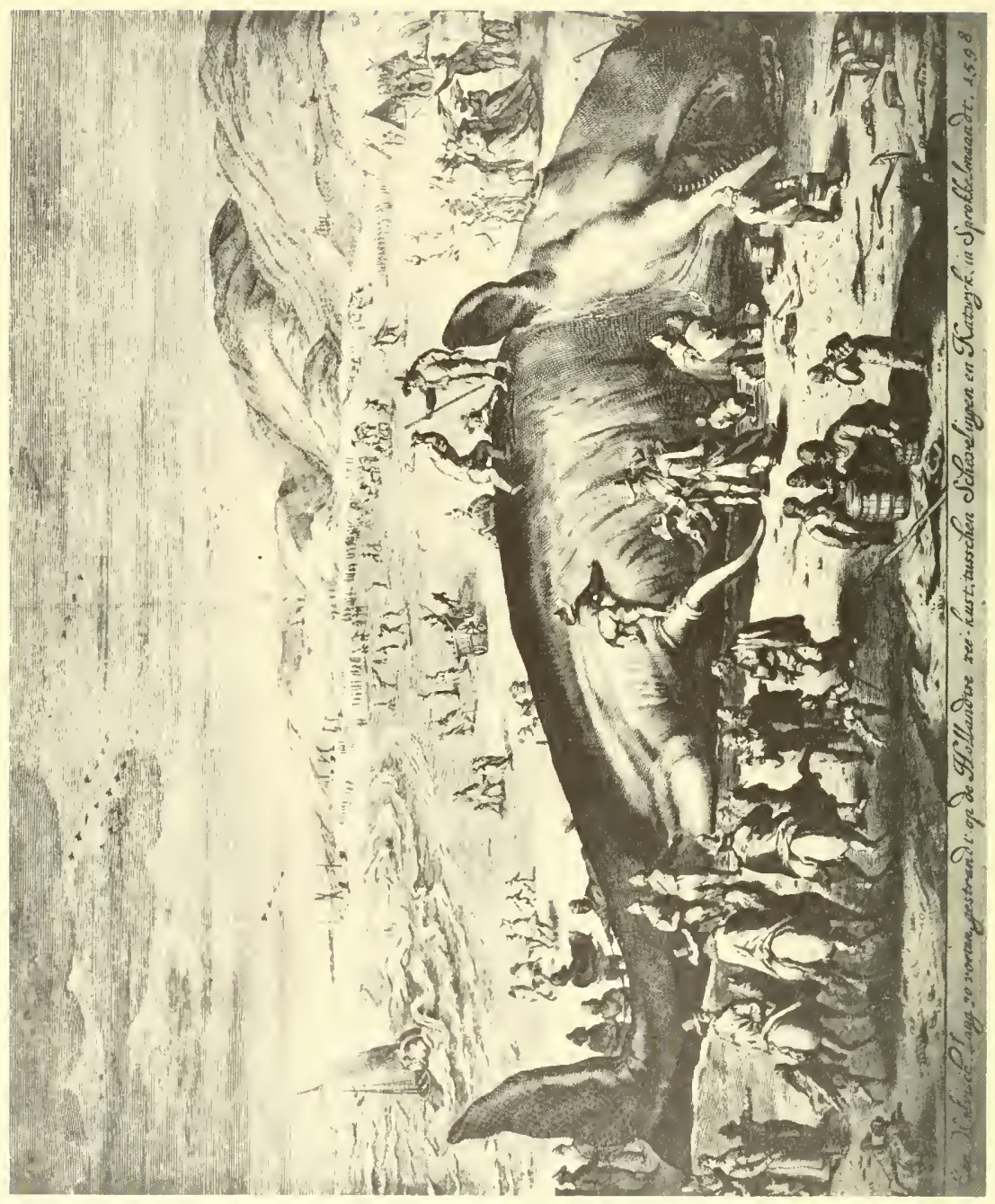

马

3

는

을

कि

0 넝

Ð 3

당

ह ज्ञ

总㸿

(롤

ङ

$\lesssim$ ¿

a क

○.

స $\frac{\pi}{3}$

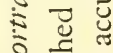

ㄴ. 뭉

च

๑ $\cong$

드

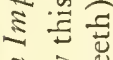

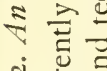

(ن)

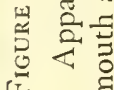




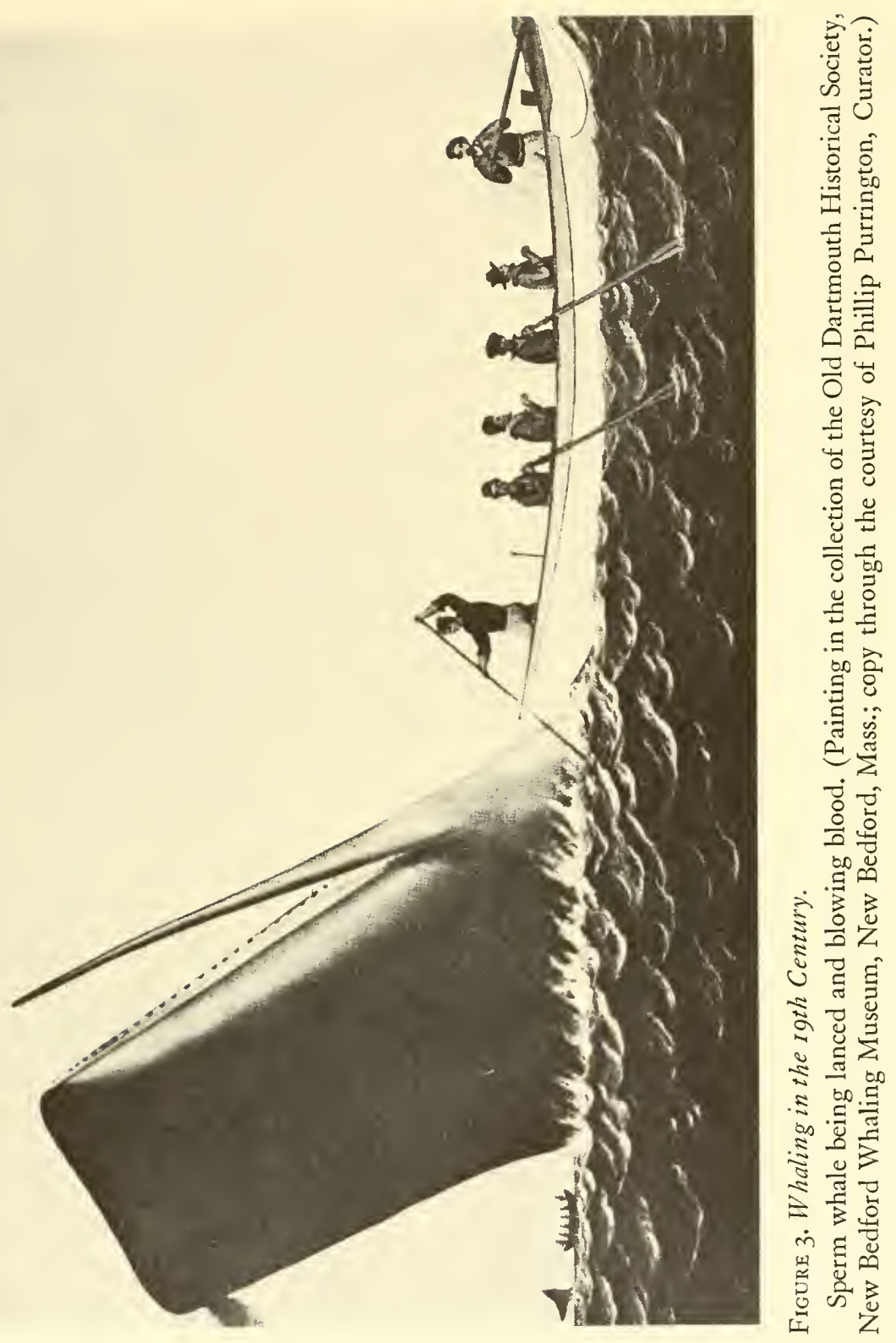




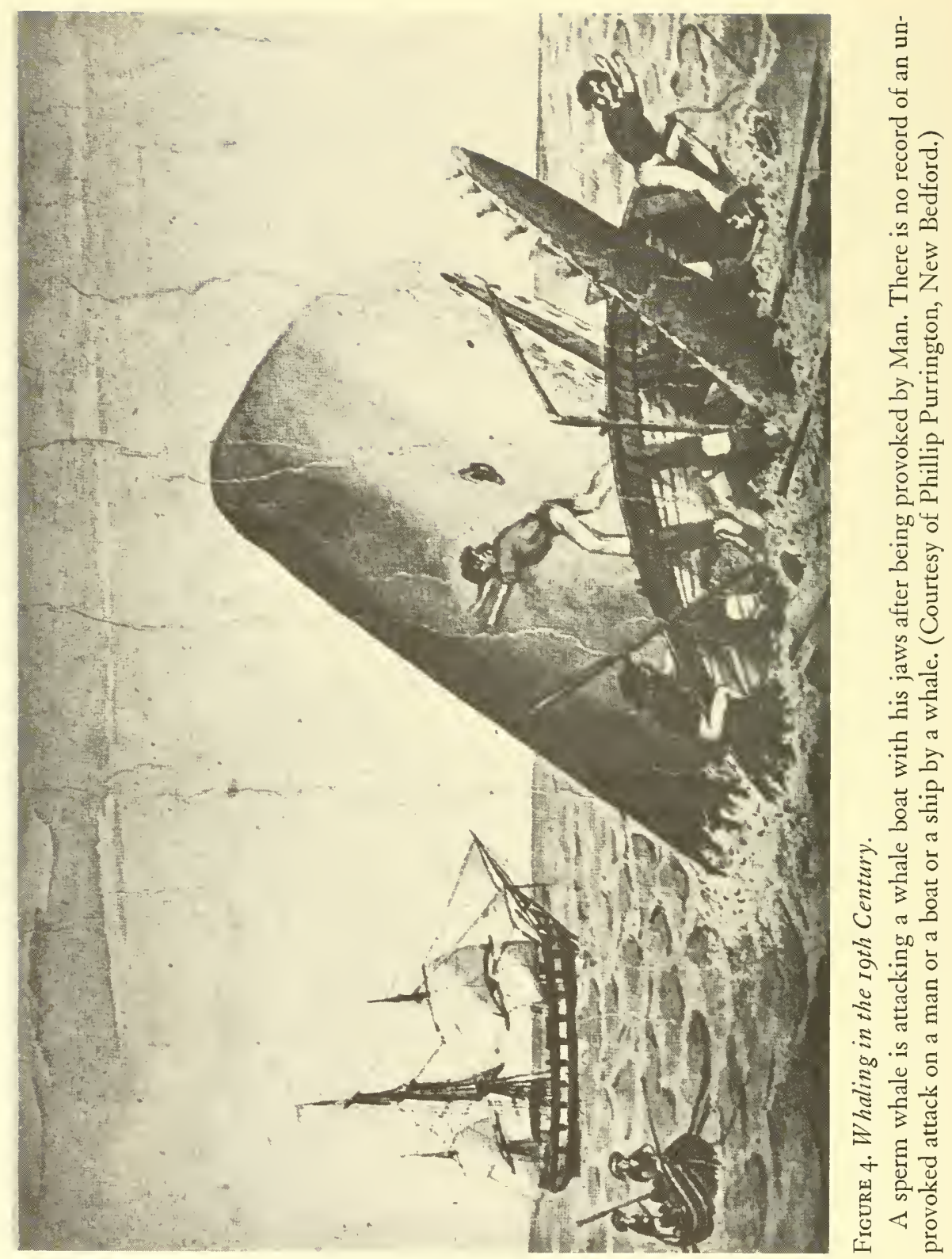



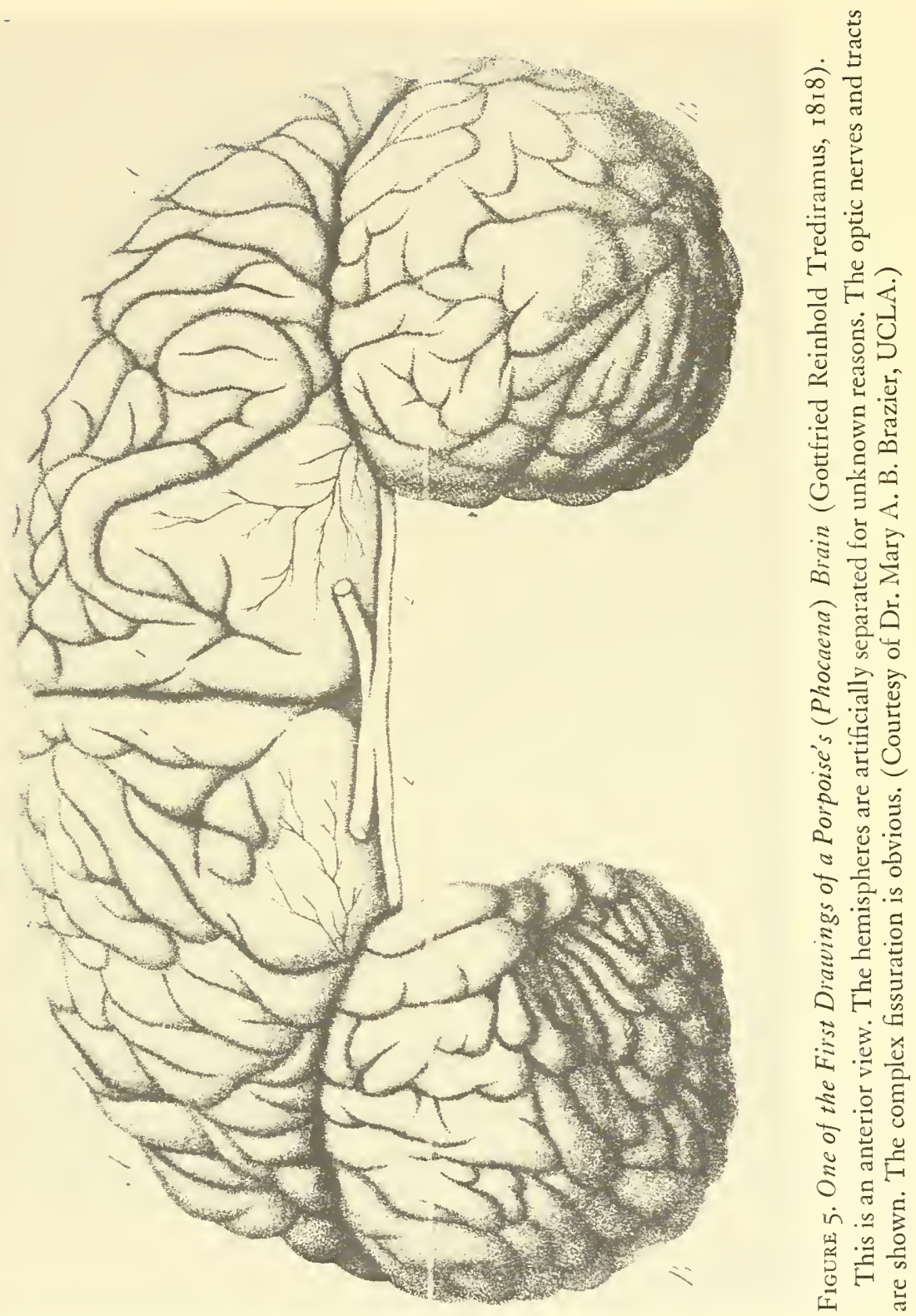


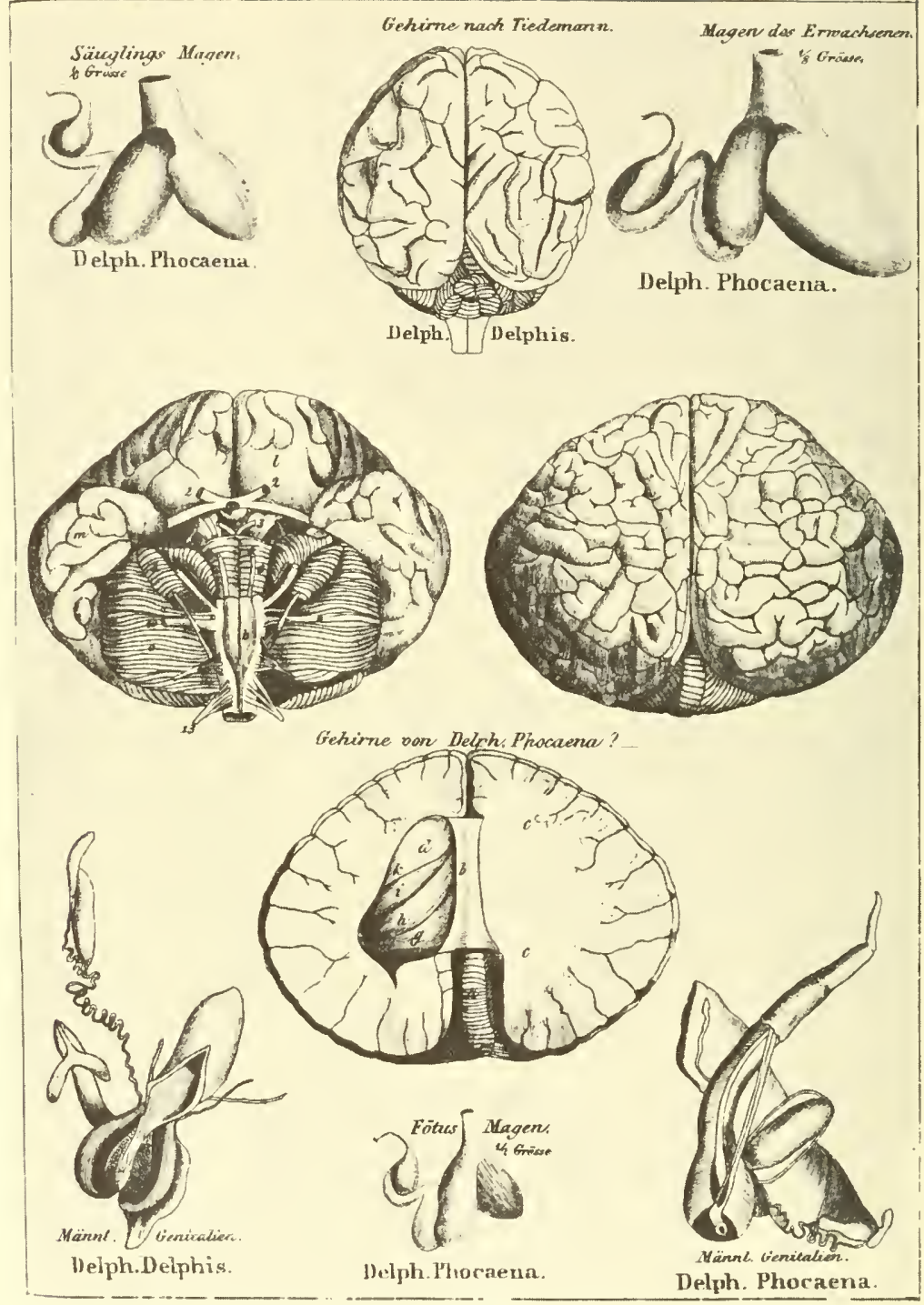

Figure 6. Early Drawings of the Brain of the Dolphin and of the Porpoise by Tiedemann.

These drawings were reproduced by H. G. L. Reichenbach in his Anatomia Mammalium in 1845 . These are more accurate renditions and show the lateral expansion of these fine brains. (Courtesy of the Library of Congress, Washington, D.C.) 


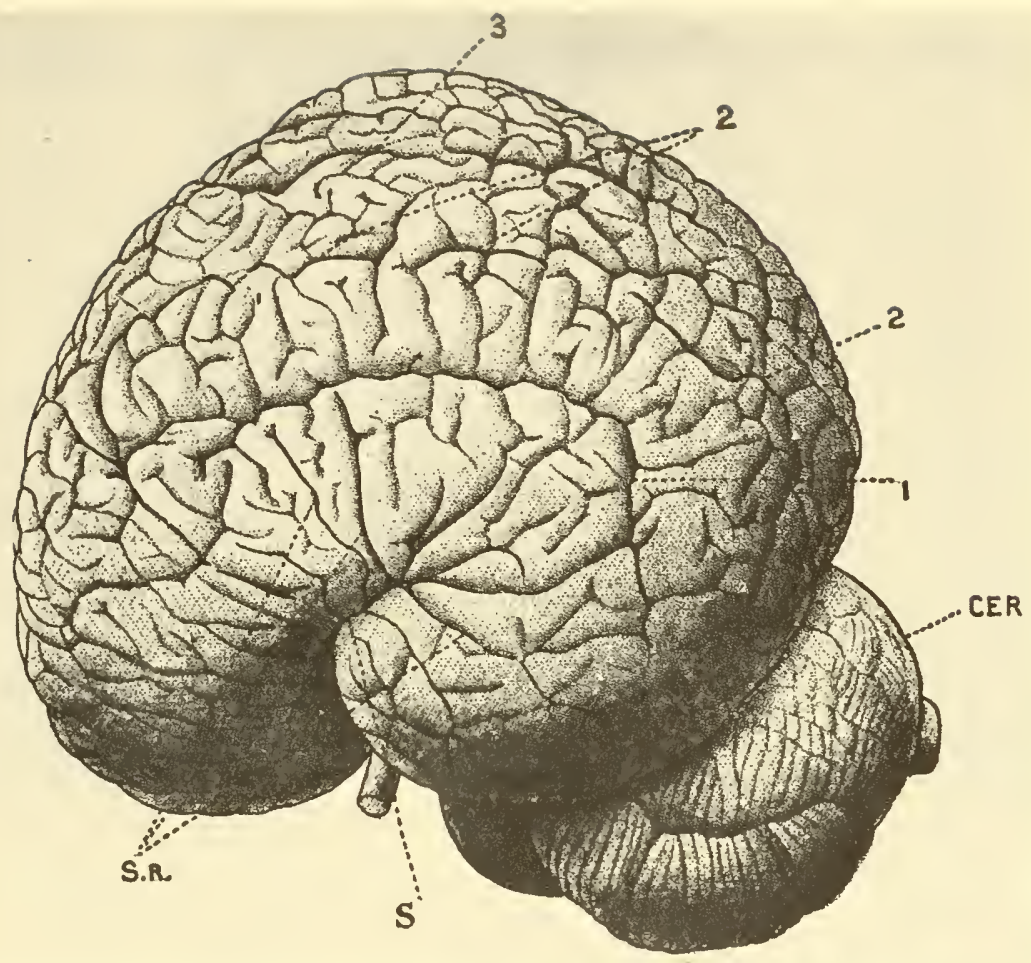

Figrre 7. The First 2oth-Century Drauing of a Dolphin Brain (G. Elliot Smith, 1902).

Lateral view. The proportions are excellent, as are the gyri and sulci. Smith gives the species as Delphinus tursio; this probably corresponds to the modern Tursiops truncatus or bottlenose dolphin. This brain closely resembles that of Tursiops shown in photos in reference 7. Langworthy's 1931 drawings ("Porpoise") are also similar (Brain, 54, 225, 1931). 


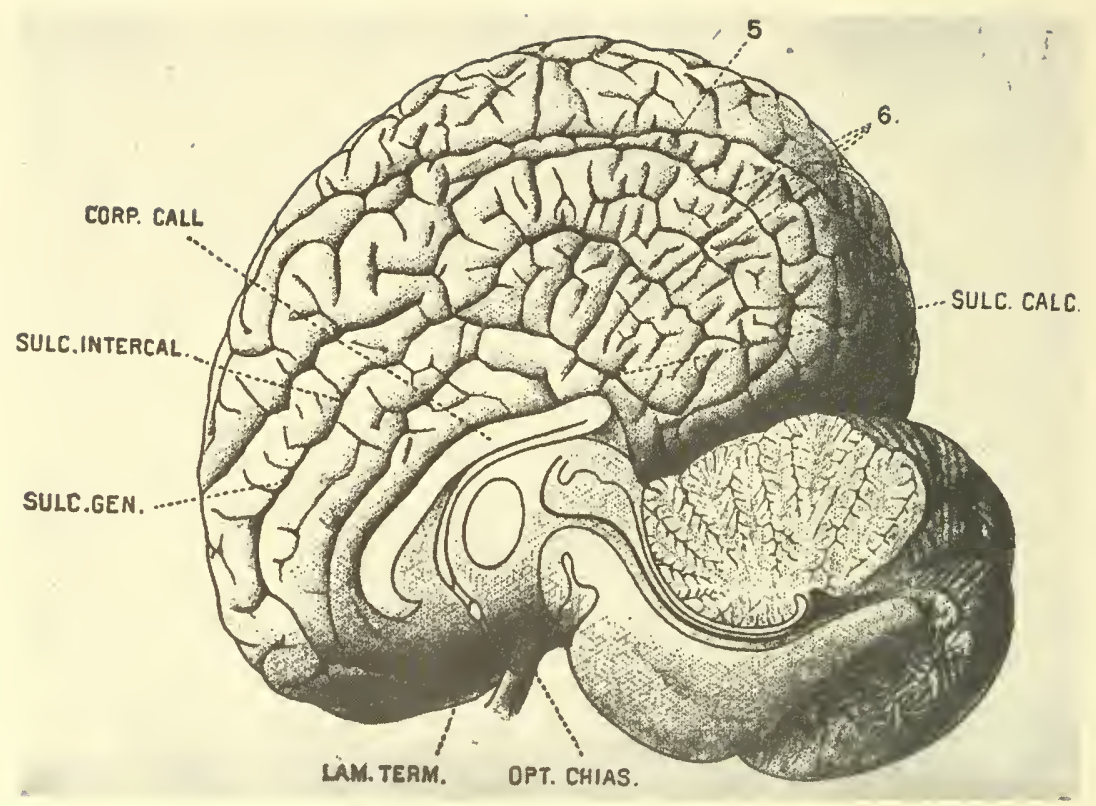

Figure 8. Mesial View of Same Brain as in Figure 7. 
We demonstrated that, like other animals, the monkey, the rat, etc., these animals can be rewarded by stimulating the proper places in their brains. ${ }^{18.18}$ In a recent series of experiments we have been establishing the controls necessary to understanding what brain rewards mean in terms of natural physiology. We have demonstrated quite formally that rubbing the skin of these animals with our hands is a rewarding experience to them; they will seek it vocally and by body gestures and give certain kinds of performance in order to obtain this reward.

Recently we have found that "vocal transactions" are a reward to these animals. ${ }^{7,13}$ (See below for human analogies in the child.) This seems to be one of the basic factors in our being able to elicit humanoid emissions. The vocal transactions are started by a human shouting some words over the water of the tank in which the animal is residing. A single word may be used or many words-it makes little difference. Eventually the animal in the tank will raise his blowhole out of water and make some sort of a humanoid emission or whistle or clicks in a delphinese fashion. If the human immediately replies with some word or words, the animal may immediately respond, the human answers, and a vocal transaction is under way. We have shown that dolphins naturally do this with one another in both their whistle and clicking spheres, and sometimes do it in the barking sphere. ${ }^{13}$ How much of this is "instinctual" and how much is not, there is no way of knowing at the present time.

A physical analysis of such vocal transactions shows them to be formally quite as complex as the vocal transactions between human beings. In other words, the dolphin may say one word or a syllable-like emission, or many, one right after the other, as may the humans. If the human says one word, the dolphin may say one, two, three, or four, and if the human says one, two, three, or four, the dolphin may say one. There is no necessary master-slave kind of relationship in the delphinic emissions.

In our early reports we gave examples which were single 
words which sounded like the words that the human made. This presentation led to misunderstandings among our scientific colleagues. It looked as if the animals were doing a slavish tape-recorder rendition of what we were doing in a fashion similar to that of a parrot or a Mynah bird. All along we have known that the dolphins did not do such a slavish job and were obviously doing a much more complicated series of actions. We are just beginning to appreciate how to analyze and what to analyze in these transactions. As I stated in Man and Dolphin about $10 \%$ of these emissions sound like human speech. In other words, the dolphin is "saying" far more than we have transmitted to the scientific community to date. We hesitate to say anything more about this until we begin to understand what is going on in greater detail. We are making progress slowly.

Let me then make an appeal to you-a long appeal to your logical and rational views of man and cetaceans. Here I review the above points in more general terms, and develop a plea for a new science-a new discipline combining the best of science with the best of the humanities.

Several old questions should be revived and asked again with a new attitude, with more modern techniques of investigation and with more persistence. It may take twenty years or more to develop good answers; meanwhile the intellectual life of man will profit in the undertaking. There is something exciting and even at times disturbing in this quest. ${ }^{10}$ The bits and pieces may have started before historical times. In each age of man a new fragment was allowed to be recorded and passed on to subsequent generations. Each generation judged and rejudged the evidence from the older sources on the basis of its then current beliefs and on the basis of its new experiences, if any. At times good evidence was attenuated, distorted, and even destroyed in the name of the then current dogma.

Today we have similar problems; our current beliefs blind us, too. Evidence right before the eye can be distorted by the 
eye of the beholder quite as powerfully as it has been in previous ages of man. We can only hope that we have achieved greater insight and greater objectivity than some of our ancestors. The winds and currents of bias and prejudice blow hard and run deep in the minds of men. In one's own mind these factors are difficult to see, and when seen, difficult to attenuate and to allow for their influence. If at times I scold my own species, do not take it too personally; I am scolding myself more than you.

You can see by now that I believe that some of the answers to the quest are in our own minds. We must develop, imaginatively and humbly, numbers of alternative hypotheses to expand the testable areas of the intellect and bring to the investigation new mental instruments to test and to collect facts germane to our questions.

To ask about the intelligence of another species, we somehow first ask: how large and well-developed is its brain? Somewhat blindly we link brain size (a biological fact) to intelligence (a behavioral and psychological concept). We know, in the case of our own species, that if the brain fails to develop, intelligence also fails to develop.

How do we judge in our own species that intelligence develops or fails to develop? We work with the child and carefully observe its performances of common tasks and carefully measure its acquisition of speech quantitatively. We measure (among other factors) size of word vocabulary, adequacy of pronunciation, lengths of phrases and sentences, appropriateness of use, levels of abstraction achieved, and the quality of the logical processes used. We also measure speed of grasping new games with novel sets of rules and strategy; games physical and/or games verbal and vocal.

Normal mental growth patterns of human children have been measured extensively in both performance and in vocal speech acquisition. I have taken the liberty of relating these to the normal growth of brain weight of children. 


\section{TABLE I}

Threshold Quantities for Human Acquisition of

Speech: Age and Brain Weight

\begin{tabular}{|c|c|c|}
\hline $\begin{array}{c}\text { Age } \\
\text { (months) }\end{array}$ & $\begin{array}{l}\text { Brain weight } \\
\text { (grams) }\end{array}$ & $\begin{array}{c}\text { Speech stages } \\
\text { (first appearances) }\end{array}$ \\
\hline 2 & 480 & $\begin{array}{l}\text { Responds to human voice, cooing, } \\
\text { and vocalizes pleasure. }\end{array}$ \\
\hline 4 & 580 & $\begin{array}{l}\text { Vocal play. Eagerness and dis- } \\
\text { pleasure expressed vocally. }\end{array}$ \\
\hline 6 & 660 & Imitates sounds. \\
\hline 9 & 770 & First word. \\
\hline I I & 850 & $\begin{array}{l}\text { Imitates syllables and words. } \\
\text { Second word. }\end{array}$ \\
\hline 13 & 930 & Vocabulary expands rapidly. \\
\hline 17 & 1,030 & Names objects and pictures. \\
\hline $2 \mathrm{I}$ & 1,060 & Combines words in speech. \\
\hline 23 & 1,070 & $\begin{array}{l}\text { Uses pronouns, understands } \\
\text { prepositions, uses phrases } \\
\text { and sentences. }\end{array}$ \\
\hline
\end{tabular}

${ }^{1}$ Lilly, John C. Man and Dolphin: A Developing Relationship. London: Victor Gollancz, 1962.

${ }^{2}$ Boston Children's Hospital data from I,I9 8 records, in Coppoletta, J. M., and Wolbach, S. B., "Body Length and Organ Weights of Infants and Children," American Journal of Pathology, IX (1933), 55-70.

${ }^{3}$ Summarized from McCarthy, Dorothea, "Language Development in Children," in Carmichael, Leonard, ed., Manual of Child Psychology. New York: John Wiley, 1946, pp. $476-58 \mathrm{r}$.

Table I shows relations between age, brain weight, and speech performance, up to 23 months, 1070 grams, and the use of full sentences. By I7 years, the brain reaches and levels off at $145^{\circ}$ grams and the number of words, levels of abstraction, etc., are so large as to be difficult to assess.

In these processes, what are the minimum necessary but not necessarily sufficient factors? $?^{20}$ On the biological side, modern theory concentrates on two factors: total numbers of neurons and the number of interconnections between them. On the psychological side, modern theory concentrates on the numbers of occurrences of reinforced contingencies experienced, the num- 
ber of repetitions, and the number of adequate presentations from the accepted set of the consensus known as "native language," and the total numbers of sets in the stored memories at a given age. In addition, of course, is the adequate development of the transmitting and of the receiving equipment needed for speech and its ancillary behaviors.

On the biological side, modern neurology says the number of neurons in the human brain reaches maximum value before birth at about $\mathrm{I} 3$ billions. After this point, the increase in weight consists of increased numbers of fibers, increased connections, increased size of elements, and increased efficiency and selectivity of transmission. Thus the increase in weight of the human brain from about 400 to 1400 grams seems to be devoted to improving its internal (as well as external) communication, storage, and computation networks. As I have stated elsewhere (Man and Dolphin), it is my impression that there exist critical threshold values in the brain's growth pattern at which certain kinds of performance become possible. Complex speech acquisition seems related to brain weights of 800 to Iooo grams, but no smaller. This assumes, of course, numbers of neurons $\left(\mathrm{Io}^{10}\right)$ and numbers of connections and opportunities for learning and time to learn commonly found with humans.

The critical psychological factors in speech acquisition are slowly being dug out and described. ${ }^{21,20}$ Among these the most important seem to be a continuous background of presentations to the child in rewarding circumstances of speech and its close relations to objects, actions, satisfaction of needs, and persons. Imitation of one's use of facial and vocal apparatus appears spontaneously in the happy child. The virtuosity of the child as a mimic is truly astonishing.

I am also impressed by evidence for what I call the "transactional drive." A bright child seems to seek and respond best to those persons who respond in kind, back and forth in exchanges of sounds and linked actions. For example, if one starts such a 
transaction with a child of 22 months with a loud word, if he is ready, he may return his version of the word or a slight variant; if one replies with another variant the child replies with still a third, or even suddenly with a new word, and so on back and forth in a transactional vocal dance. Or one may reply to a child who invites such an exchange to begin. Such exchanges seem to function as rewards of themselves, and hence the name, "transactional drive." This phenomenon is more than mere mechanical slavish mimicry. It seems to aid in perfecting pronunciation, increases vocabulary, increases the bonds with other persons, serves to substitute the "consensus-dictionary" words for the private baby words, and is thus essential to learning a language of one's own species. It is thus that the child "becomes human."

As the child ages and grows, the exchanges lengthen, and the time during which each member of the dyad is quiet while the other speaks becomes longer, until finally for a half hour or so, I am lecturing and you are at least quiet, if not listening.

How does all of this relate to modern dolphins, porpoises, and whales? From the vast array of scientific facts and theories about our own species, a few of those which I feel are useful in approaching another species to evaluate its intelligence are discussed above. But before I make connections there, let us attenuate some interfering attitudes and points of view, some myths not so modern; these interfering presumptions can be stated as follows:

(r) No animal has a language comparable to a human language.

(2) No animal is as intelligent as man.

(3) Man can adapt himself to any environment quite as well as any animal.

(4) Intelligence and intellect can be expressed only in the ways man expresses or has expressed them.

(5) All animal behavior is instinct-determined.

(6) None of man's thought and behavior is so determined. 
(7) Only man thinks and plans; animals are incapable of having a mental life.

(8) Philosophy and contemplative and analytic thought are characteristic only of man, not of any animal.

All of these statements stem from ignorance and anthropocentricity. For example, who are we to say that whales, dolphins, and porpoises are to be included as "dumb beasts"? It would be far more objective and humble to tell the truth-we don't know about these animals because we haven't "been there yet." We have not lived in the sea, naked and alone, or even in mobile groups, without steel containers to keep out the sea itself. For purposes of discussion let us make the following assumptions which push counter to the current of bias running deep among us:

( $\mathrm{r}$ Man has not yet been willing to investigate the possibility of another intelligent species.

(2) Whales, dolphins, and porpoises are assumed to be "dumb beasts" with little or no evidence for this presumption.

(3) We do not yet know very much about these animals-their necessities, their intelligences, their lives, the possibility of their communications.

(4) It is possible for man to investigate these matters objectively with courage and perseverance.

(5) To properly evaluate whales, dolphins, porpoises, we must use everything we have intellectually, all available knowledge, humanistic as well as scientific.

Our best knowledge of ourselves as a species, as humans, is in the humanities and in the budding, growing sciences of man. In pursuit of understanding of the whales, dolphins, and porpoises, we need, at least at the beginning, a large view which is in the human sciences and in the humanities. The sciences of animals are necessarily restrictive in their view, and hence not yet applicable to our problems.

The history of the animal sciences shows that they have had grave difficulties with the fact that the observers are present and 
human. These sciences, like physics, chemistry, and biology, play the game as if the human observer were not there and the systems were isolated from man. This is fine strategy for "man-less nature" studies and quite appropriate for such studies.

However, I submit to you another view, for a science of man and animal, their relationships to one another. Modern man and modern dolphin and whale may be best investigated in the framework of a new science one might call "anthropo-zoology" or "zoo-anthropology." This science is a deep study of man, of the animal, of their mutual relations, present and potential. In this discipline scientists encourage close relations with the animal, and study the developing relation between man and socalled "beast."

For the last three years in the Communication Research Institute $^{23}$ we have been pursuing an investigative path in this new science with the pair "man and bottlenose dolphin." We have encouraged and pursued studies in classical sciences such as neurophysiology, animal psychology, anatomy, biophysics, and zoology. We have also initiated and pursued this new science of the man and dolphin relation; these "homo-delphic" studies, if you will, are triply demanding: we must not only know our animal objectively but we must know man objectively, and ourselves subjectively. We cannot fight shy of involving ourselves in the investigation as objects also. In this science man, and hence one's own self, are part of the system under investigation. This is not an easy discipline. One must guard quite as rigorously (or even more so) against the pitfalls of wishful thinking and sensational fantasy as in other scientific endeavors. This field requires a self-candor, an inner honesty, and a humility quite difficult to acquire. But I maintain that good science can be done here, that the field is a proper one for properly trained and properly motivated investigators. 


\section{REFERENCES AND NOTES}

I. Plinius Secundus. Natural History. III, Book IX.

2. Aristotle. Historia Animalium. Books I-IX.

3. Donaldson, Henry H. The Growth of the Brain. London: Walter Scott, 1895 .

4. Smith, G. Elliot, in Royal College of Surgeons of England, Museum, Descriptive and Illustrated Catalogue of the Physiological Series of Comparative Anatomy. London: Taylor and Francis, Ig02, $\mathrm{pp} \cdot 349,35 \mathrm{I}, 356$.

5. Scammon, Charles Melville. The Marine Mammals of the NorthWestern Coast of North America, Described and Illustrated: Together with an Account of the American Whale-Fishery. San Francisco: J. H. Carmany, 1874, p. 78.

6. von Bonin, Gerhardt. "Brain-Weight and Body-Weight in Mammals," Journal of General Psychology, XVI (1937), 379-389.

7. Lilly, John C. Man and Dolphin. Garden City, N.Y.: Doubleday, 1961; London: Victor Gollancz, 1962.

8. McBride, Arthur F., and Hebb, D. O. "Behavior of the Captive Bottle-Nose Dolphin, Tursiops truncatus," Journal of Comparative and Physiological Psychology, XLI (I948), I I I-I23.

9. Griffin, Donald R. Echoes of Bats and Men. Garden City, N.Y.: Doubleday, 1959.

Io. Kellogg, Winthrop N. Porpoises and Sonar. Chicago: University of Chicago Press, I96r.

I I. Lilly, John C., and Miller, Alice M. "Vocal Exchanges between Dolphins; Bottlenose Dolphins 'Talk' to Each Other with Whistles, Clicks, and a Variety of Other Noises," Science, CXXXIV (г961), I873-I 876.

12. Schevill, William E., and Lawrence, Barbara. "Auditory Response of a Bottlenosed Porpoise, Tursiops truncatus, to Frequencies above 100 KC," Journal of Experimental Zoology, CXXIV (I953), I $47-165$.

13. Lilly, John C. "Vocal Behavior of the Bottlenose Dolphin," Proceedings of the American Philosophical Society, CVI (I926), 520529 . 
I4. Norris, Kenneth S., Prescott, John H., Asa-Dorian, Paul V., and Perkins, Paul. "An Experimental Demonstration of Echo-Location Behavior in the Porpoise, Tursiops truncatus (Montagu)," Biological Bulletin, CXX (196r), 163-176.

I5. Lilly, John C. "Interspecies Communication," McGraw-Hill Yearbook of Science and Technology 1962. New York: McGraw-Hill, I962, pp. 279-281.

I6. Lilly, John C. "Some Considerations Regarding Basic Mechanisms of Positive and Negative Types of Motivations," American Journal of Psychiatry, CXV (1958), 498-504.

I7. Lilly, John C. "Some Aspects of the Adaptation of the Mammals to the Ocean," in John Field, ed., Handbook of Physiology. Washington: American Physiological Society (in press).

18. Lilly, John C., and Miller, A. M. "Operant Conditioning of the Bottlenose Dolphin with Electrical Stimulation of the Brain," Journal of Comparative and Physiological Psychology, LV (1962), 73-79.

19. Lilly, John C. "Some Problems of Productive and Creative Scientific Research with Man and Dolphin," Archives of General Psychiatry (1963, in press).

20. Lilly, John C. "Critical Brain Size and Language," Perspectives in Biology and Medicine (in press).

21. Skinner, Burrhus F. Verbal Behavior. New York: AppletonCentury-Crofts, 1957 .

22. Lewis, Morris M. How Children Learn to Speak. New York: Basic Books, 1959.

23. Support for the program of the Communication Research Institute, St. Thomas, Virgin Islands, is from the National Institute of Mental Health and the National Institute of Neurological Diseases and Blindness of the National Institutes of Health; from the Coyle Foundation; from the Office of Naval Research; from the U. S. Air Force Office of Scientific Research; and from private gifts and contributions to the Communication Research Institute. 


\section{William Andrews Clark}

\section{Memorial Library}

\section{Seminar Papers}

Editing Donne and Pope. 1952.

Problems in the Editing of Donne's Sermons, by George R. Potter. Editorial Problems in Eighteenth-Century Poetry, by John Butt.

Music and Literature in England in the Seventeenth and Eighteenth Centuries. 1953.

Poetry and Music in the Seventeenth Century, by James E. Phillips. Some Aspects of Music and Literature in the Eighteenth Century, by Bertrand $\mathrm{H}$. Bronson.

Restoration and Augustan Prose. 1956.

Restoration Prose, by James R. Sutherland.

The Ironic Tradition in Augustan Prose from Swift to Johnson, by Ian Watt.

Anglo-American Cultural Relations in the Seventeenth and Eighteenth Centuries. 1958.

The Puritans in Old and New England, by Leon Howard.

William Byrd: Citizen of the Enlightenment, by Louis B. Wright. The Beginnings of Autobiography in England, by James M. Osborn. I959.

Scientific Literature in Sixteenth and Seventeenth Century England. $196 \mathrm{r}$.

English Medical Literature in the Sixteenth Century, by C. D. O'Malley.

English Scientific Literature in the Seventeenth Century, by A. Rupert Hall.

Francis Bacon's Intellectual Milieu. A Paper delivered by Virgil K. Whitaker at a meeting at the Clark Library, i8 November 196r, celebrating the 4ooth anniversary of Bacon's birth.

Methods of Textual Editing, by Vinton A. Dearing. 1962. 








